\title{
Characterization of primary and secondary wood combustion products generated under different burner loads
}

\author{
E. A. Bruns ${ }^{1}$, M. Krapf ${ }^{1}$, J. Orasche ${ }^{2,3,4}$, Y. Huang ${ }^{2}$, R. Zimmermann ${ }^{2,3,4}$, L. Drinovec ${ }^{5}$, G. Močnik ${ }^{5}$, I. El-Haddad ${ }^{1}$, \\ J. G. Slowik ${ }^{1}$, J. Dommen ${ }^{1}$, U. Baltensperger ${ }^{1}$, and A. S. H. Prévôt ${ }^{1}$ \\ ${ }^{1}$ Laboratory of Atmospheric Chemistry, Paul Scherrer Institute, 5232 Villigen, Switzerland \\ ${ }^{2}$ Joint Mass Spectrometry Centre, Cooperation Group “Comprehensive Molecular Analytics”, Helmholtz Zentrum München, \\ 85764 Neuherberg, Germany \\ ${ }^{3}$ Joint Mass Spectrometry Centre, Institute of Chemistry, Division of Analytical and Technical Chemistry, University of \\ Rostock, 18057 Rostock, Germany \\ ${ }^{4}$ Helmholtz Virtual Institute of Complex Molecular Systems in Environmental Health-Aerosol and Health (HICE), \\ www.hice-vi.eu \\ ${ }^{5}$ Aerosol d.o.o, Kamniška 41, 1000 Ljubljana, Slovenia
}

Correspondence to: A. S. H. Prévôt (andre.prevot@psi.ch)

Received: 16 September 2014 - Published in Atmos. Chem. Phys. Discuss.: 17 October 2014

Revised: 22 January 2015 - Accepted: 13 February 2015 - Published: 12 March 2015

\begin{abstract}
Residential wood burning contributes to the total atmospheric aerosol burden; however, large uncertainties remain in the magnitude and characteristics of wood burning products. Primary emissions are influenced by a variety of parameters, including appliance type, burner wood load and wood type. In addition to directly emitted particles, previous laboratory studies have shown that oxidation of gas-phase emissions produces compounds with sufficiently low volatility to readily partition to the particles, forming considerable quantities of secondary organic aerosol (SOA). However, relatively little is known about wood burning SOA, and the effects of burn parameters on SOA formation and composition are yet to be determined. There is clearly a need for further study of primary and secondary wood combustion aerosols to advance our knowledge of atmospheric aerosols and their impacts on health, air quality and climate.

For the first time, smog chamber experiments were conducted to investigate the effects of wood loading on both primary and secondary wood combustion products. Products were characterized using a range of particle- and gasphase instrumentation, including an aerosol mass spectrometer (AMS). A novel approach for polycyclic aromatic hydrocarbon (PAH) quantification from AMS data was developed and results were compared to those from GC-MS analysis of filter samples.
\end{abstract}

Similar total particle mass emission factors were observed under high and average wood loadings; however, high fuel loadings were found to generate significantly higher contributions of PAHs to the total organic aerosol (OA) mass compared to average loadings. PAHs contributed $15 \pm 4 \%$ (mean \pm 2 sample standard deviations) to the total OA mass in highload experiments, compared to $4 \pm 1 \%$ in average-load experiments. With aging, total OA concentrations increased by a factor of $3 \pm 1$ for high load experiments compared to $1.6 \pm 0.4$ for average-load experiments. In the AMS, an increase in PAH and aromatic signature ions at lower $m / z$ values, likely fragments from larger functionalized PAHs, was observed with aging. Filter samples also showed an increase in functionalized PAHs in the particles with aging, particularly oxidized naphthalene species. As PAHs and their oxidation products are known to have deleterious effects on health, this is a noteworthy finding to aid in the mitigation of negative wood burning impacts by improving burner operation protocols. 


\section{Introduction}

Residential wood combustion is a notable source of atmospheric aerosols, particularly in regions with moderate to cold climate, as it is a common heating method. For example, during the winter, residential wood combustion was found to contribute between 17 and $49 \%$ to submicron organic aerosol mass at various rural and urban sites throughout central Europe (Lanz et al., 2010); between 9 and $64 \%$ to total particulate carbon at six rural sites in Portugal, France, Germany, Austria and Hungary (Gelencsér et al., 2007); an average of $\sim 41 \%$ to organic carbon in Fresno (USA) (Gorin et al., 2006); an average of $79 \%$ to organic carbon in Prague (Czech Republic) (Saarikoski et al., 2008); 13-15\% to primary submicron aerosol and up to $66 \%$ to total submicron aerosol in Paris (France) (Crippa et al., 2013; Petit et al., 2014); 31-83\% to $\mathrm{PM}_{1}$ in northern Sweden (Krecl et al., 2008 ); and $30-60 \%$ to organic carbon in various European alpine locations (Herich et al., 2014). Globally, it is estimated that approximately 3 billion people burn biomass or coal for residential heating and cooking needs (IPCC, 2007).

Although wood combustion is known to contribute to the global aerosol burden, large uncertainties in aerosol composition and quantification remain. Aerosol characterization is important for ambient source apportionment and for understanding impacts on health (Naeher et al., 2007; Mauderly and Chow, 2008; Bølling et al., 2009), air quality (FinlaysonPitts and Pitts, 2000) and climate (IPCC, 2013). Direct particulate emissions from wood combustion are a complex mixture of organic compounds, inorganic compounds, elemental and/or black carbon, and metals (Fine et al., 2001, 2002a, 2004a; Hedberg et al., 2002; Johansson et al., 2004; Schmidl et al., 2008), making characterization difficult. Previous studies have shown that organics often constitute more than $50 \%$ of particulate emissions (Schauer et al., 2001; Fine et al., 2002b; Hedberg et al., 2002; Schmidl et al., 2008; Elsasser et al., 2013), making this an important class of compounds to characterize. However, characterization is complicated by burn variability, both during a single fire and between individual fires (Weimer et al., 2008; Heringa et al., 2012; Elsasser et al., 2013; Eriksson et al., 2014). Burn parameters, such as wood type, wood loading and appliance type, can also influence emission composition greatly (McDonald et al., 2000; Fine et al., 2002b; Jordan and Seen, 2005; Weimer et al., 2008; Pettersson et al., 2011; Orasche et al., 2012, 2013; Elsasser et al., 2013; Eriksson et al., 2014).

Gases emitted together with primary organic aerosol (POA) can undergo oxidation in the atmosphere to form lower-volatility compounds, which condense to form secondary organic aerosols (SOA) (Kroll and Seinfeld, 2008). However, most previous laboratory studies of residential wood burning have only characterized primary emissions after undergoing varying degrees of cooling and dilution (McDonald et al., 2000; Fine et al., 2001, 2002a, b, 2004a, b; Schauer et al., 2001; Hedberg et al., 2002; Johansson et al.,
2004; Schmidl et al., 2008; Weimer et al., 2008; Orasche et al., 2012, 2013; Elsasser et al., 2013; Eriksson et al., 2014). The few laboratory studies investigating SOA formation from residential wood burning have shown that it can be substantial; aged OA was 1.8-5.3 times that of POA for log wood burners during stable burning conditions (Grieshop et al., 2009a, b; Hennigan et al., 2010; Heringa et al., 2011). Also, phenol, syringol and guaiacol, which have been identified in primary biomass burning emissions, form SOA in laboratory studies (Yee et al., 2013). There is evidence of SOA formation from residential wood burning in ambient measurements as well (Iinuma et al., 2010; Mohr et al., 2013). For example, methyl-nitrocatechols, reaction products from the oxidation of $m$-cresol, present in primary wood smoke, have been measured in significant quantities in rural Germany (Iinuma et al., 2010). The extent to which wood combustion SOA is included in ambient measurements is unclear and more work is needed to characterize SOA quantities and composition. For example, $59 \%$ of the carbon in semi- and low-volatility oxygenated organic aerosol (largely secondary) measured during winter in Barcelona consists of non-fossil carbon, suggesting this is from sources such as biomass burning and cooking (Mohr et al., 2012). Improved understanding of wood burning SOA is also needed to improve modeling results (Simpson et al., 2007).

PAHs are formed during incomplete combustion, emitted during wood burning (McDonald et al., 2000; Schauer et al., 2001; Hedberg et al., 2002; Fine et al., 2004b; Jordan and Seen, 2005; Fitzpatrick et al., 2007; Bari et al., 2011; Pettersson et al., 2011; Eriksson et al., 2014), and of particular interest due to their deleterious effects on health (Kim et al., 2013). Functionalized PAHs, such as oxygenated or nitrogenated compounds, can be emitted directly during burning or can form in the atmosphere from the oxidation of parent PAHs, and these heteroatom derivatives often have higher toxicity than their PAH analogues (Yu, 2002; Fu et al., 2012). Recently, increased PAH emissions were observed under highly loaded burner conditions (Elsasser et al., 2013; Orasche et al., 2013; Eriksson et al., 2014). However, no work has been published on the effect of burner fuel load on SOA.

Here, we present results from the first smog chamber investigation of the impact of wood load on the quantities and composition of primary and secondary residential wood combustion products. Online measurements were made with a high-resolution time-of-flight aerosol mass spectrometer (AMS) and compared to results from offline filter analysis, with a particular focus on PAH emissions and their evolution with aging.

\section{Methods}

Six wood combustion experiments using beech wood with a moisture content of $10 \pm 2 \%$ (mean \pm 2 sample standard 
deviations, $2 \mathrm{SD}$ ) were conducted in a $27 \mathrm{~m}^{3}$ smog chamber (Paulsen et al., 2005) to investigate the effects of wood loading on primary emissions and secondary products. Three of the experiments (1-3, Table 1$)$ were conducted with a starting wood load of $2.21 \pm 0.09 \mathrm{~kg}$ (three $\operatorname{logs}$ without bark, four pieces of kindling and three fire starters comprised of pine wood shavings, paraffin and natural resin) and three experiments (4-6, Table 1) were conducted with a starting wood load of $7.4 \pm 0.2 \mathrm{~kg}$ (nine logs without bark, eight pieces of kindling and four fire starters) in the $\sim 0.037$ $\mathrm{m}^{3}$ burner combustion chamber of a modern log wood burner (Avant, Attika) (Fig. S1 in the Supplement). Hereafter, these two cases are referred to as "average load" and "high load", respectively. Prior to each burn, ash and residue from the previous burn were removed. Each burn began with ignition of the fire starters using a hand-held lighter and immediately closing the burner door. The damper was left completely open to allow maximum air flow into the combustion chamber until the logs caught fire $(\sim 10-15 \mathrm{~min})$, after which the air flow was reduced.

Before each experiment, the chamber was cleaned by injecting $\mathrm{O}_{3}$ for 6 to $8 \mathrm{~h}$ and irradiating with a set of $80 \mathrm{UV}$ lights (100 W, Cleo Performance, Philips) (Platt et al., 2013) for at least $10 \mathrm{~h}$ while flushing with pure air $\left(120 \mathrm{~L} \mathrm{~min}^{-1}\right.$, 737-250 series, AADCO Instruments Inc.). The chamber was then flushed with pure air in the dark for at least $20 \mathrm{~h}$. After cleaning, the chamber was partially filled with humidified pure air. Wood was combusted as described above and emissions were sampled from the chimney, diluted using two ejector dilutors in parallel (DI-1000, Dekati Ltd.) and injected into the chamber. Lines from the chimney to the smog chamber, the ejection diluters and the dilution air (equal mixture of air purified from 737-250 series, AADCO Instruments Inc. and 250 series, AADCO Instruments Inc.) were heated to $473 \mathrm{~K}$ to reduce line losses of semi-volatile compounds due to condensation of the hot emissions. The total dilution ratios of the raw emissions after the dilutors ranged from 13.6 to 15 . Emissions underwent another dilution of roughly a factor of 5-20, depending on the experiment, when injected into the chamber. The average temperature and relative humidity in the chamber after emission injection was $294.0 \pm 0.5 \mathrm{~K}$ and $60 \pm 5 \%$, respectively.

Emission injection into the chamber began at least $15 \mathrm{~min}$ after ignition to ensure that the emissions were not influenced by fire starters. Injection continued until either flames were no longer visible or the desired mass concentration was reached in the chamber, which ranged from 41 to $82 \mathrm{~min}$ for experiments 1-5. Experiment 6 was performed in a similar manner, except at the end of the flaming phase, the injection into the chamber was stopped and two batches of two additional logs each were added to the burner. The second and third injection into the chamber began after the new logs caught fire (approximately 2-4 min after addition) for a total injection period of $113 \mathrm{~min}$.
A burn proceeds through phases: a starting phase, at least one stable flaming phase and a smoldering phase, all of which can have different chemical profiles. Emissions are typically more variable during the start and smoldering phase than the flaming stage. To isolate the effect of fuel loading, only emissions from the flaming phase were sampled. In this study, the average modified combustion efficiency (MCE), defined as the ratio of $\mathrm{CO}_{2(g)}$ to the sum of $\mathrm{CO}_{2(g)}$ and $\mathrm{CO}_{(g)}$ (Ward and Radke, 1993), of the injected emissions was greater than 0.90 for each experiment (Table 1), indicating injected emissions were dominated by the flaming phase (Lee et al., 2010).

After injection, the gaseous and particulate emissions in the chamber were characterized using a variety of online and offline techniques described below. Following approximately $2 \mathrm{~h}$ of primary emissions measurements, the toxicological responses of human epithelia cells to the particle emissions were investigated (presented in a future publication). During the cell exposures, particles were sampled at $\sim 80 \mathrm{~L} \mathrm{~min}^{-1}$ from the chamber. This necessitated refilling the partially empty chamber during the exposure with humidified pure air.

After exposing the cells to primary emissions and the concurrent refilling of the chamber, a 9-times deuterated butanol sample (butanol-D9, $98 \%$, Cambridge Isotope Laboratories) was injected into the chamber. This compound was monitored $\left(\left[\mathrm{M}-\mathrm{H}_{2} \mathrm{O}+\mathrm{H}\right]^{+}\right.$fragment, $m / z$ 66) using a proton transfer reaction time-of-flight mass spectrometer (PTRMS, $\left[\mathrm{H}_{3} \mathrm{O}\right]^{+}$reagent ion, Ionicon Analytik $\mathrm{GmbH}$ ) to calculate $\mathrm{OH}$ exposures in the chamber, using a rate constant of $3.4 \times 10^{-12} \mathrm{~cm}^{3} \mathrm{molec}^{-1} \mathrm{~s}^{-1}$ (Barmet et al., 2012). The PTR-MS was not used during experiments 3 and 6.

In addition to the butanol-D9 injection, a continuous injection of nitrous acid (HONO), which dissociates upon irradiation $(\lambda<400 \mathrm{~nm})$ to form hydroxyl radical $(\mathrm{OH})$, began 30 $35 \mathrm{~min}$ prior to the start of photooxidation. The HONO was generated and injected by bubbling pure air $\left(2.5 \mathrm{~L} \mathrm{~min}^{-1}\right)$ through a mixture of $\mathrm{H}_{2} \mathrm{SO}_{4}(95-97 \%$, Merck) in water $(10 \mathrm{mM}, 18.0 \mathrm{M} \Omega \mathrm{cm}$, Milli-Q, Reference $\mathrm{A}+)$ and $\mathrm{NaNO}_{2}$ in water $(1 \mathrm{mM}$ experiments $1,2,4,5 ; 3 \mathrm{mM}$ experiments 3,$6 ; \geq 99.0 \%$, Fluka) and passing through a particle filter into the chamber (Taira and Kanda, 1990; Pfaffenberger et al., 2013). Finally, the emissions were aged with UV light for $4.5-16 \mathrm{~h}$, corresponding to maximum $\mathrm{OH}$ exposures of $\sim(2-5) \times 10^{7}$ molec cm $^{-3} \mathrm{~h}$ in experiments $1,2,4$ and 5 . A significant increase in OA upon photooxidation was observed during all experiments, and after the maximum OA concentration was reached, a second cell exposure and chamber refill was performed.

Primary and secondary particle- and gas-phase products were characterized using a variety of online and offline techniques. In the gas phase, $\mathrm{CO}_{2}, \mathrm{CO}$ and $\mathrm{CH}_{4}$ (Picarro Inc.); $\mathrm{O}_{3}$ (S300 ozone analyzer, Environics); total hydrocarbons (THC, model VE 7 THC analyzer with flame ionization detector, J.U.M.); and $\mathrm{NO}, \mathrm{NO}_{2}$ and $\mathrm{NO}_{\mathrm{x}}$ (trace level $42 \mathrm{C}$, Thermo Environmental Instruments with a photocatalytic 
Table 1. Characterization of primary gas-phase and particle-phase emissions measured from the smog chamber.

\begin{tabular}{|c|c|c|c|c|c|c|c|c|c|c|c|c|c|c|c|c|c|c|}
\hline Expt. & $\begin{array}{l}\text { Wood load } \\
(\mathrm{kg})\end{array}$ & $\begin{array}{l}\text { Wood burned } \\
\text { per chamber air } \\
\text { volume }\left(\mathrm{g} \mathrm{m}^{-3}\right)^{\mathrm{b}}\end{array}$ & MCE & $\begin{array}{l}\mathrm{CO}_{2} \\
\left(\mathrm{~g} \mathrm{~kg}^{-1}\right)^{\mathrm{b}}\end{array}$ & $\begin{array}{l}\mathrm{CO} \\
\left(\mathrm{g} \mathrm{kg}^{-1}\right)^{\mathrm{b}}\end{array}$ & $\begin{array}{l}\mathrm{CH}_{4} \\
\left(\mathrm{~g} \mathrm{~kg}^{-1}\right)^{\mathrm{b}}\end{array}$ & $\begin{array}{l}\mathrm{THC} \\
\left(\mathrm{g} \mathrm{kg}^{-1}\right)^{\mathrm{b}}\end{array}$ & $\begin{array}{l}\text { Total PM } \\
\left(\mathrm{g} \mathrm{kg}^{-1}\right)^{\mathrm{b}}\end{array}$ & $\begin{array}{l}\text { Organic } \\
\left(\mathrm{mg} \mathrm{kg}^{-1}\right)^{\mathrm{a}, \mathrm{b}}\end{array}$ & $\begin{array}{l}\text { PAH } \\
\left(\mathrm{mg} \mathrm{kg}^{-1}\right)^{\mathrm{b}}\end{array}$ & $\begin{array}{l}\mathrm{BC} \\
\left(\mathrm{mg} \mathrm{kg}^{-1}\right)^{\mathrm{b}}\end{array}$ & $\begin{array}{l}\mathrm{NO}_{3} \\
\left(\mathrm{mg} \mathrm{kg}^{-1}\right)^{\mathrm{b}}\end{array}$ & $\begin{array}{l}\mathrm{SO}_{4} \\
\left(\mathrm{mg} \mathrm{kg}^{-1}\right)^{\mathrm{b}}\end{array}$ & $\begin{array}{l}\mathrm{NH}_{4} \\
\left(\mathrm{mg} \mathrm{kg}^{-1}\right)^{\mathrm{b}}\end{array}$ & $\begin{array}{l}\mathrm{Cl} \\
\left(\mathrm{mg} \mathrm{kg}^{-1}\right)^{\mathrm{b}}\end{array}$ & $\mathrm{OM}: \mathrm{BC}^{\mathrm{b}}$ & $0: \mathrm{C}^{\mathrm{c}}$ & $\mathrm{H}: \mathrm{C}^{\mathrm{c}}$ \\
\hline 1 & 2.17 & $0.562 \pm 0.008$ & 0.96 & $1740 \pm 50$ & $42.8 \pm 0.9$ & $2.93 \pm 0.05$ & $5.8 \pm 0.3$ & $0.81 \pm 0.02$ & $700 \pm 20$ & $27 \pm 2$ & $75 \pm 1$ & $18 \pm 1$ & $5.8 \pm 0.3$ & $3.6 \pm 0.3$ & $2.07 \pm 0.09$ & $9.4 \pm 0.2$ & $0.376 \pm 0.002$ & $1.521 \pm 0.006$ \\
\hline 2 & 2.21 & $0.635 \pm 0.004$ & 0.96 & $1740 \pm 20$ & $43.8 \pm 0.3$ & $4.02 \pm 0.03$ & $5.7 \pm 0.2$ & $0.260 \pm 0.005$ & $154 \pm 5$ & $5.2 \pm 0.8$ & $86 \pm 2$ & $9.7 \pm 0.8$ & $2.8 \pm 0.2$ & $1.6 \pm 0.2$ & $0.59 \pm 0.08$ & $1.79 \pm 0.06$ & $0.475 \pm 0.006$ & $1.45 \pm 0.01$ \\
\hline 3 & 2.26 & $0.5227 \pm 0.0001$ & 0.96 & $1773.1 \pm 0.9$ & $31.65 \pm 0.08$ & $2.368 \pm 0.001$ & $2.3 \pm 0.1$ & $0.227 \pm 0.009$ & $60 \pm 9$ & $2.8 \pm 0.5$ & $153 \pm 9$ & $9.6 \pm 0.7$ & $2.1 \pm 0.3$ & $1.5 \pm 0.2$ & $0.24 \pm 0.07$ & $0.39 \pm 0.06$ & $0.40 \pm 0.01$ & $1.447 \pm 0.008$ \\
\hline 4 & 7.47 & $1.239 \pm 0.004$ & 0.96 & $1730 \pm 10$ & $51.3 \pm 0.2$ & $4.07 \pm 0.02$ & $6.53 \pm 0.07$ & $0.132 \pm 0.002$ & $78 \pm 2$ & $13.1 \pm 0.8$ & $45.6 \pm 0.3$ & $5.3 \pm 0.3$ & $2.0 \pm 0.2$ & $0.58 \pm 0.04$ & $0.60 \pm 0.06$ & $1.72 \pm 0.05$ & $0.255 \pm 0.007$ & $1.133 \pm 0.008$ \\
\hline 5 & 7.49 & $0.669 \pm 0.001$ & 0.97 & $1743 \pm 6$ & $45.9 \pm 0.1$ & $2.872 \pm 0.004$ & $4.58 \pm 0.06$ & $0.174 \pm 0.002$ & $40 \pm 2$ & $5.4 \pm 0.5$ & $119.8 \pm 0.6$ & $10.4 \pm 0.6$ & $1.8 \pm 0.2$ & $1.2 \pm 0.2$ & $0.33 \pm 0.07$ & $0.33 \pm 0.01$ & $0.36 \pm 0.01$ & $1.09 \pm 0.01$ \\
\hline 6 & 7.34 & $1.6908 \pm 0.0003$ & 0.94 & $1701.4 \pm 0.7$ & $64.96 \pm 0.05$ & $4.717 \pm 0.003$ & $7.65 \pm 0.04$ & $0.172 \pm 0.003$ & $59 \pm 3$ & $8.1 \pm 0.4$ & $105 \pm 2$ & $5.0 \pm 0.2$ & $2.4 \pm 0.2$ & $0.56 \pm 0.04$ & $1.16 \pm 0.08$ & $0.56 \pm 0.03$ & $0.305 \pm 0.008$ & $1.205 \pm 0.007$ \\
\hline
\end{tabular}

converter and 9841A $\mathrm{NO}_{\mathrm{x}}$ analyzer, Monitor Labs) were measured.

Non-refractory particle chemical composition and size were measured using a high-resolution (HR) time-of-flight AMS (Aerodyne Research Inc.) (DeCarlo et al., 2006) operated in $\mathrm{V}$ mode with a $2.5 \mu \mathrm{m}$ inlet lens (Williams et al., 2013). Two Aethalometers each measured black carbon mass concentrations at seven wavelengths (Magee Scientific Aethalometer model A33, Aerosol d.o.o.). A thermal desorber comprised of a $50 \mathrm{~cm}$ heating section held at $423 \mathrm{~K}$ followed by a $50 \mathrm{~cm}$ denuder section was located directly upstream of one Aethalometer to volatilize and remove organic species (Burtscher et al., 2001). A condensation particle counter (CPC, 3025A TSI) measured total particle number concentrations and a scanning mobility particle sizer (SMPS, CPC 3022, TSI, and custom built DMA with a length of $0.44 \mathrm{~m}$ ) measured particle size distributions. Particles were dried (Nafion, Perma Pure LLC) upstream of the AMS, Aethalometers, SMPS and CPC.

Losses in the thermal desorber were determined by nebulizing $\mathrm{NaCl}$ ( $\geq 99.5 \%$, Fluka) in water and passing through the thermal desorber. Size distributions were measured using an SMPS before and after the thermal desorber. It was determined that $24 \%$ of the mass is lost in the thermal desorber at a mobility diameter of $100 \mathrm{~nm}$ and $9 \%$ of the mass is lost at a mobility diameter of $200 \mathrm{~nm}$. The average mobility diameter of the particles after injection ranged from 50 to $120 \mathrm{~nm}$ and losses were accounted for using the data collected at a mobility diameter of $100 \mathrm{~nm}$.

Additionally, particles were collected on filters $(47 \mathrm{~mm}$ Tissuquartz, Pall Corporation, $26 \mathrm{~L} \mathrm{~min}^{-1}$ for 30-32 min) after injection of the primary emissions and after observation of the maximum OA signal during aging. Prior to deposition on the filter, particles were sampled through a charcoal denuder to remove organic gases. Filters were immediately stored at $253 \mathrm{~K}$ until analysis. Filters were analyzed by in situ-derivatization thermal desorption gas chromatography time-of-flight mass spectrometry (IDTD-GC-TOF-MS) as described by Orasche et al. (2011). Briefly, a small portion of each filter was spiked with internal standards (isotopically labeled compounds; Orasche et al., 2011) and N-methyl-N(trimethylsilyl)-trifluoroacetamide (MSTFA) was added before and subsequently during a thermal extraction period by introduction into a carrier gas stream. Thermally desorbed and derivatized molecules were transferred onto the cold GC column and the GC-MS run was started with pure carrier gas. Filter analysis from experiment 2 is not available.

\section{Data analysis}

\subsection{Wall loss and dilution}

Particles in the chamber can be lost to the walls due to diffusion, electrostatic deposition or gravitational settling. In previous wood burning chamber studies (Grieshop et al., 2009a, b; Hennigan et al., 2011; Heringa et al., 2011), changes in the black carbon concentration, calculated from light absorption at longer wavelengths (i.e., 880 or $950 \mathrm{~nm}$ ), were assumed to be solely due to wall losses. The decay of BC was used to correct other particulate concentrations (e.g., organics) for wall losses, assuming all particles are lost equally to the walls. However, the condensation of organics on black carbon particles can increase measured absorption, even at longer wavelengths (Shiraiwa et al., 2010). Despite the thermal desorber upstream of the Aethalometer, an increase in absorption at all measured wavelengths was observed during the rapid increase in organic compounds that immediately followed the initiation of photooxidation. This could be due to organics remaining on the particles or charring of organic material in the desorber. The desorption/adsorption of semivolatile material on the filter during sampling can also influence absorption. As the magnitude of this effect varies with increasing mass on the filter, taking this effect into account is difficult. Because calculated wall loss rates are sensitive to small changes in the measured black carbon concentration, wall loss rates were instead determined by fitting the decay in number concentration measured by the SMPS or CPC. For experiments 1, 4 and 5, data were fit for $1 \mathrm{~h}$ prior to aging until turning the lights, where coagulation is expected to be negligible, and for the longer experiments 3 and 6, data were fit at the end of the experiment. The particle half-lives in the chamber for these experiments were in good agreement with each other $(7 \pm 2 \mathrm{~h})$ and in the range measured previously for this chamber (Paulsen et al., 2005). The mean half-life was assumed for experiment 2 , where reliable number concentration data were not available. The method described in Weitkamp et al. (2007) was used to take wall losses into account, assuming condensable material partitions only to suspended particles. However, as shown by Zhang et al. (2014), wall losses of semi-volatile species remain uncertain. The 
wall loss rate constant, which is dependent on particle size, is not expected to change greatly following the coagulation period immediately after injection, as the particle mass mean diameter changed less than $100 \mathrm{~nm}$ for all experiments except experiment 6.

The wall loss correction was applied after the emissions were injected and well mixed in the chamber, approximately 15-50 min after the end of the injection, until the end of the experiment. Concentrations were also corrected for dilution during chamber refilling by using $\mathrm{CH}_{4}$ as an inert tracer. Gasphase measurements were corrected for dilution in the same manner.

\subsection{Emission factors}

Emission factors (EFs) of various species $i, S_{i}$, were determined using Eq. (1) (Andreae and Merlet, 2001):

$\mathrm{EF}_{S_{i}}=\frac{\Delta S_{i}}{\Delta C_{\mathrm{CO}_{2}}+\Delta C_{\mathrm{CO}}+\Delta C_{\mathrm{HC}}+\Delta C_{\mathrm{OC}}+\Delta C_{\mathrm{BC}}} \times f_{\mathrm{C}}$,

where $\Delta S_{i}$ is the background-corrected concentration of species $i, \Delta C_{\mathrm{CO}_{2}}$ is the background-corrected $\mathrm{CO}_{2}$ concentration, $\Delta C_{\mathrm{CO}}$ is the background-corrected $\mathrm{CO}$ concentration, $\Delta C_{\mathrm{HC}}$ is the background-corrected hydrocarbon concentration, $\Delta C_{\mathrm{OC}}$ is the background-corrected organic carbon concentration, $\Delta C_{\mathrm{BC}}$ is the background-corrected black carbon concentration, and $f_{\mathrm{C}}$ is the carbon fraction of beech wood, estimated to be 0.5 (Joosten et al., 2004). HR-AMS data were used to determine the organic mass to organic carbon (OM : OC) ratio for each experiment (Aiken et al., 2008). The average OM : OC of the primary emissions for the average load experiments was $1.7 \pm 0.1$ and was $1.56 \pm 0.05$ for the high load experiments.

\subsection{AMS analysis}

AMS data were analyzed in Igor Pro 6.3 (WaveMetrics) using the SQUIRREL (version 1.53F) and PIKA (1.12F) data analysis programs.

Extensive fragmentation of most compounds is observed in AMS mass spectra due to the vaporization-ionization process. During data analysis, the mass spectral signal is separated into different compound classes (i.e., organics, nitrate, sulfate, ammonium and chloride) using known fragmentation patterns for unit mass resolution (UMR) data (Allan et al., 2004) or using ion assignments determined from high-resolution (HR) analysis. Unlike most organic compounds, PAHs undergo relatively little fragmentation in the AMS vaporization-ionization process, making it possible to positively identify PAH base ions $\left([\mathrm{M}]^{+}\right)$. In addition to base ions, some associated fragment ions are observed (e.g., $[\mathrm{M}-\mathrm{H}]^{+},[\mathrm{M}-2 \mathrm{H}]^{+}$and $[\mathrm{M}+\mathrm{H}]^{+}$) (Dzepina et al., 2007). $\mathrm{PAH}$ base ions and associated ions can also be doubly charged (e.g., $\left[\mathrm{C}_{16} \mathrm{H}_{10}\right]^{+}=m / z 202.08$ and $\left[\mathrm{C}_{16} \mathrm{H}_{10}\right]^{2+}=$ $m / z$ 101.04). For singly charged ions at odd nominal masses, this results in doubly charged ions at roughly half-integer masses (e.g., $\left[\mathrm{C}_{16} \mathrm{H}_{9}\right]^{+}=m / z \quad 201.07$ and $\left[\mathrm{C}_{16} \mathrm{H}_{9}\right]^{2+}=$ $m / z$ 100.54).

PAH quantification from AMS data is not often reported, even when PAHs are in relatively high abundance (Elsasser et al., 2013), due to data analysis challenges. UMR quantification of PAH and non-PAH contribution at the same nominal mass and incorporation of signal at half-integer masses is difficult (Dzepina et al., 2007). HR analysis allows for the quantification of ions at half-integer masses and the ability to distinguish between multiple ions at the same nominal mass. However, the number of possible molecular assignments and ion peak widths both increase with increasing $\mathrm{m} / \mathrm{z}$, making $\mathrm{PAH}$ assignment and separation from non-PAH signal at the same nominal mass difficult.

Dzepina et al. (2007) measured PAH standards and ambient PAHs with a quadrupole AMS and developed a method to analyze PAHs separately from organics. In the ambient measurements, contribution at higher $m / z$ values from non-PAH compounds further complicated PAH quantification. Based on the analysis of laboratory standards, a method was developed for quantifying PAHs. However, Dzepina et al. (2007) used a quadrupole AMS during these measurements and thus only UMR data were available. Here, HR data provide more information for PAH quantification. For this study, PAHs were analyzed as a subclass of organics, using a combination of UMR and HR analysis to maximize the advantages of both methods.

The UMR analysis fragmentation table was modified with input from the HR analysis. To reduce uncertainty in peak fitting due to increasing number of chemically reasonable ion assignments at higher masses, HR data were fit only for masses below $m / z$ 200. Peaks above $m / z 200$ were fit only if the peak measured during primary emissions could be fit solely with a formula corresponding to a PAH and yielded a fit residual less than $5 \%$. Peak fit examples are shown in Fig. S2 in the Supplement. To achieve satisfactory fitting in the higher $m / \mathrm{z}$ range, PAH ions with sufficiently high signal to noise were used in the determination of the $\mathrm{m} / z$ calibration and peak width parameters. All signal at PAH base peaks above $m / z 200$ is considered PAH, which may neglect non-PAH contributions. However, the quality of the peak fits in Fig. S2 in the Supplement is high, suggesting that the non-PAH signal at these masses is relatively low. This method also results in some mass above $m / z 200$ considered non-PAH, which may be PAH-related. If all the mass above $m / z 200$ categorized as non-PAH was actually PAH-related, the PAH signal would increase by $\sim 50-90 \%$ for the primary emissions.

PAH base ions included in the analysis are shown in Table 2. Signal from $[\mathrm{M}]^{2+},[\mathrm{M}-\mathrm{H}]^{+},[\mathrm{M}-\mathrm{H}]^{2+},[\mathrm{M}-2 \mathrm{H}]^{+}$, $[\mathrm{M}+\mathrm{H}]^{+},[\mathrm{M}+\mathrm{H}]^{2+}$ and isotopic contributions from each of the singly charged ions from the presence of a single ${ }^{13} \mathrm{C}$, referred to as associated ions hereafter, for each nonoxygenated PAH base ion were included in the analysis. 
Table 2. PAH base ions included in the AMS analysis.

\begin{tabular}{lc}
\hline Ion & Nominal $m / z$ \\
\hline$\left[\mathrm{C}_{10} \mathrm{H}_{8}\right]^{+}$ & 128 \\
{$\left[\mathrm{C}_{11} \mathrm{H}_{7}\right]^{+}$} & 139 \\
{$\left[\mathrm{C}_{12} \mathrm{H}_{8}\right]^{+}$} & 152 \\
{$\left[\mathrm{C}_{13} \mathrm{H}_{7}\right]^{+}$} & 163 \\
{$\left[\mathrm{C}_{13} \mathrm{H}_{9}\right]^{+}$} & 165 \\
{$\left[\mathrm{C}_{12} \mathrm{H}_{8} \mathrm{O}\right]^{+}$} & 168 \\
{$\left[\mathrm{C}_{14} \mathrm{H}_{8}\right]^{+}$} & 176 \\
{$\left[\mathrm{C}_{14} \mathrm{H}_{10}\right]^{+}$} & 178 \\
{$\left[\mathrm{C}_{15} \mathrm{H}_{9}\right]^{+}$} & 189 \\
{$\left[\mathrm{C}_{13} \mathrm{H}_{8} \mathrm{O}_{2}\right]^{+}$} & 196 \\
{$\left[\mathrm{C}_{16} \mathrm{H}_{7}\right]^{+}$} & 199 \\
{$\left[\mathrm{C}_{16} \mathrm{H}_{10}\right]^{+}$} & 202 \\
{$\left[\mathrm{C}_{18} \mathrm{H}_{10}\right]^{+}$} & 226 \\
{$\left[\mathrm{C}_{17} \mathrm{H}_{10} \mathrm{O}\right]^{+}$} & 230 \\
{$\left[\mathrm{C}_{20} \mathrm{H}_{12}\right]^{+}$} & 252 \\
{$\left[\mathrm{C}_{22} \mathrm{H}_{12}\right]^{+}$} & 276 \\
{$\left[\mathrm{C}_{24} \mathrm{H}_{12}\right]^{+}$} & 300 \\
{$\left[\mathrm{C}_{24} \mathrm{H}_{14}\right]^{+}$} & 302 \\
\hline
\end{tabular}

From the HR analysis, it was observed that the oxygenated PAHs do not have significant signal at the (non-isotopic) associated ions listed above, likely due to fragmentation differences from the presence of oxygen atom. There are considerable PAH signals as low as $m / z 128$ (Fig. 1), which if interpreted as an unfragmented species would indicate naphthalene; however, this compound is expected to be fully in the gas phase (Pankow, 1994). Therefore, this suggests that the PAH signals observed in the lower $m / z$ region are likely from PAHs that have undergone fragmentation in the AMS vaporization-ionization process. The PAH ions at odd $m / z$ 's are also likely fragments, as observed by Bente et al. (2009).

PAH base ions typically yield higher signals than their associated ions and are thus less prone to interference from non-PAH signal. To reduce uncertainty in quantification at the associated ions, particularly during oxidation when the PAH fraction decreases due to reaction of PAHs and/or production of non-PAH ions, the ratio of the base ion to each associated ion was determined from the primary emissions. This ratio was then incorporated into the UMR fragmentation table and applied to the entire data set. These ratios are influenced by instrumental parameters and are assumed to not change greatly during the short period in which these experiments were performed. Thus, these ratios were determined from a single experiment (experiment 4 , with the highest fraction of PAHs) and applied to all experiments. Figure S3 in the Supplement shows the ratios of associated ions to the base ion for base peaks at $m / z$ 202, 226 and 276 during this experiment. These ratios were relatively stable during the $\sim 7 \mathrm{~h}$ primary emission measurement period, including during dilution. There were difficulties in determining accurate ratios of the smallest $\mathrm{PAH}$ ion, $\left[\mathrm{C}_{10} \mathrm{H}_{8}\right]^{+}$, and the associated
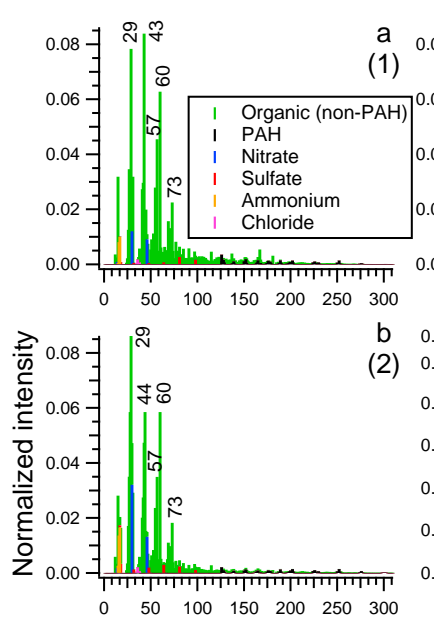

b 0.12 ユ

(2) 0.11 毛
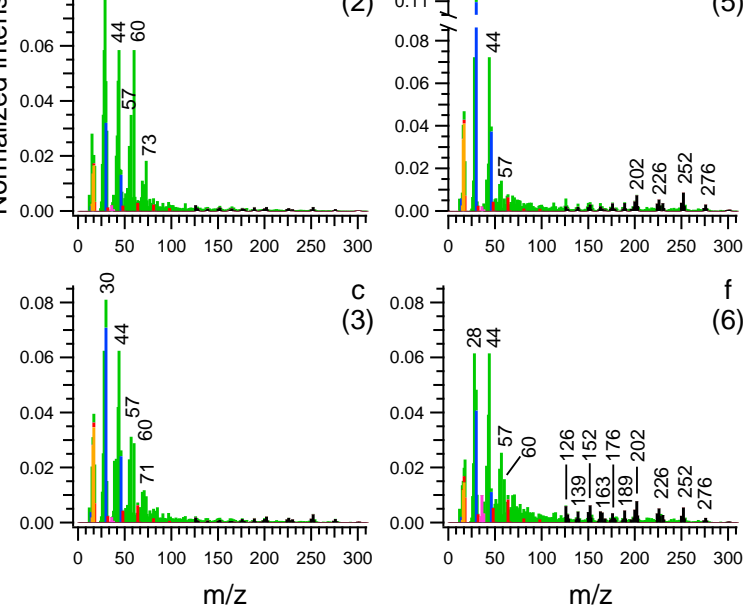

Figure 1. AMS mass spectra of organic (non-PAH) and PAH contributions to primary non-refractory particles from $(\mathbf{a}-\mathbf{c})$ average-load experiments 1-3 and from (d-f) high-load experiments 4-6, respectively. The signal is normalized to the total signal. The legend in (a) applies to (a-f).

$\left[\mathrm{C}_{10} \mathrm{H}_{6}\right]^{+}$. For this PAH and associated ions, ratios were determined individually for each experiment.

The doubly charged ions from even mass base ions overlap with other ions which may be PAH or non-PAH. Thus, the ratio of doubly charged to singly charged ions from all odd mass base ions was used to calculate the doubly charged signal from even mass base ions. For presentation of mass spectra herein, the signal from the doubly charged ions was subtracted from the $m / z$ at which it was observed and added into the base ion signal. Also, there is overlap between some base and associated ions. For example, $[\mathrm{M}-2 \mathrm{H}]^{+}$from $\left[\mathrm{C}_{14} \mathrm{H}_{10}\right]^{+}$ is $\left[\mathrm{C}_{14} \mathrm{H}_{8}\right]^{+}$. In these cases, for example, $\left[\mathrm{C}_{14} \mathrm{H}_{8}\right]^{+}$was treated as a base ion, and thus the ratio of $\left[\mathrm{C}_{14} \mathrm{H}_{10}\right]^{+}$to the $[\mathrm{M}-2 \mathrm{H}]^{+}$was not included in the analysis. The ratio of $[\mathrm{M}]^{+} /[\mathrm{M}-\mathrm{H}]^{+}$was used, and thus $[\mathrm{M}+\mathrm{H}]^{+}$from $\left[\mathrm{C}_{14} \mathrm{H}_{8}\right]^{+}$ was not calculated.

For analysis requiring software tools only available for use with HR data (e.g., determination of elemental ratios), not all mass is accounted for due to difficulties in fitting above $\mathrm{m} / \mathrm{z} 200$. However, the fraction of organic mass not included was less than $10 \%$ for all experiments for primary emissions and decreased to less than $4 \%$ during aging. 
HR data were used exclusively for nitrate, sulfate, ammonium and chloride quantification. For quantification, the relative ionization efficiency (RIE) of PAHs was assumed to be the same as non-PAH organics (i.e., 1.4). As with several recent laboratory biomass burning studies (Hennigan et al., 2011; Heringa et al., 2011, 2012; Ortega et al., 2013; Eriksson et al., 2014), a collection efficiency of 1 was used for all experiments.

The AMS PAH analysis is subject to uncertainties. PAHs may be underestimated due to the conservative analysis approach of only assigning compounds that are unambiguously PAHs to the PAH subclass. The PAH RIE is another possible source of error in the AMS analysis. Compared to the PAH RIE used in this study, Dzepina et al. (2007) measured similar or greater RIEs for four PAH standards $(\sim 1.35-2.1)$ and Slowik et al. (2004) measured a similar RIE for pyrene of 1.35. However, if the RIE was higher (i.e., 2.1), the reported PAH values would decrease by a factor of 1.5. Substantial formation of PAHs during the AMS vaporization process is unlikely. Flash pyrolysis of biomass material at $400-550^{\circ} \mathrm{C}$ was observed to produce very low levels of PAHs (Horne and Williams, 1996). Although the temperatures were lower than that of the AMS vaporizer $\left(600^{\circ} \mathrm{C}\right)$, the pyrolysis time was $2 \mathrm{~s}$, much longer than the $10^{-4}-10^{-5} \mathrm{~s}$ AMS vaporization process.

\subsection{Filter-based analysis}

GC-MS analysis of filter samples can provide unambiguous identification of PAH compounds not possible with AMS analysis. However, filter-based techniques are subject to both positive and negative artifacts during sampling, as well as during analysis, particularly for semi-volatile species. For example, positive artifacts can arise from the adsorption of semi-volatile species in the gas phase onto the filter, whereas evaporation of species on the filter results in negative artifacts (Turpin et al., 2000). Many of the PAHs emitted during wood combustion are semi-volatile (Hytonen et al., 2009). For example, using a modified partitioning model of Pankow (Pankow, 1994; Donahue et al., 2006), $26 \%$ of pyrene is expected to be in the gas phase at $294 \mathrm{~K}$, assuming a pyrene activity coefficient in the organic mass of 1 , a vapor pressure of $1.3 \times 10^{-4} \mathrm{~Pa}$ and a total organic aerosol mass concentration of $30 \mathrm{\mu g} \mathrm{m}^{-3}$, based on the non-wall-loss/dilution-corrected organic trace during the primary filter collection period of the high-load experiments. Positive artifacts are greatly reduced or eliminated by using a denuder upstream of the filter to remove organic gases (Subramanian et al., 2004), but this possibly results in substantial negative artifacts by altering the gas-particle equilibrium. For example, the negative artifact for OC on quartz filters with an upstream denuder was $43 \%$ of the total OC for diesel exhaust, which like wood smoke contains semi-volatiles (Zhang et al., 2012). For individual PAHs, there was a $41-70 \%$ difference between denuded and non-denuded samples (Zhang et al., 2012). However, only
PAHs with molecular weights (MWs) of 252 and 276 were reported (Zhang et al., 2012) and negative artifacts are expected to be even higher for higher volatility PAHs. When measuring wood burning emissions, Hytonen et al. (2009) found that only $80 \%$ of the true particulate PAH quantity of 15 measured PAHs (MW 152-276) were collected on the filter when using an upstream denuder, with pyrene, fluoranthene, phenanthrene and anthracene most affected. As a denuder was used in the current experiments, filter artifacts are likely to be predominately negative. Also, although a large number of PAHs were quantified, the list is likely not exhaustive (Table 3 ).

\section{Results and discussion}

For all experiments, primary particulate emissions were a mixture of organic and inorganic compounds and black carbon (Table 1). Emission factors of various species in the chamber are given in Table 1 and corresponding concentrations in the chamber are presented in Table S1 in the Supplement. Organic contribution to the total particulate matter (PM) mass was substantial in all experiments, ranging from 22 to $87 \%$ (Table 1), in agreement with the wide range reported in previous studies (Schauer et al., 2001; Hedberg et al., 2002; Fine et al., 2004b; Schmidl et al., 2008; Elsasser et al., 2013). Total PM concentrations were determined by summing BC and all species measured by AMS. Non-carbon elemental species were not measured during this study, and although they are known to be emitted from wood combustion, they are not expected to greatly influence the results, as previous studies have typically found contributions of less than $5 \%$ to the fine PM mass (Schauer et al., 2001; Hedberg et al., 2002; Fine et al., 2004b).

The total PM emission factor was similar for each experiment, except experiment 1 , for which it was over 3 times greater than the other burns due to increased organic emissions (Table 1). There were no obvious reasons why the total PM emission factor in experiment 1 was considerably higher than the other experiments. Although the MCEs were similar for all burns (Table 1), this illustrates the real-world variability of wood combustion emissions and the large range of possible emission factors from the same burner and operator. Variability is also observed in previous comparisons of highand average-load burns. Orasche et al. (2013) found total PM emission factors were a factor of about 1.4 higher for highload flaming conditions than for average loads, whereas Elsasser et al. (2013) found 4-times-higher PM emissions generated under high-load conditions compared to average-load conditions. However, it is noted the Elsasser et al. (2013) result was determined from a single measurement.

The OM: $\mathrm{BC}$ ratio varied between burns, ranging between 0.33 and 9.4, with no significant dependence on wood loading (Table 1). These values are within the large range of measurements reported in the literature, although generally lower 
Table 3. PAHs quantified from offline GC-MS analysis of filter samples.

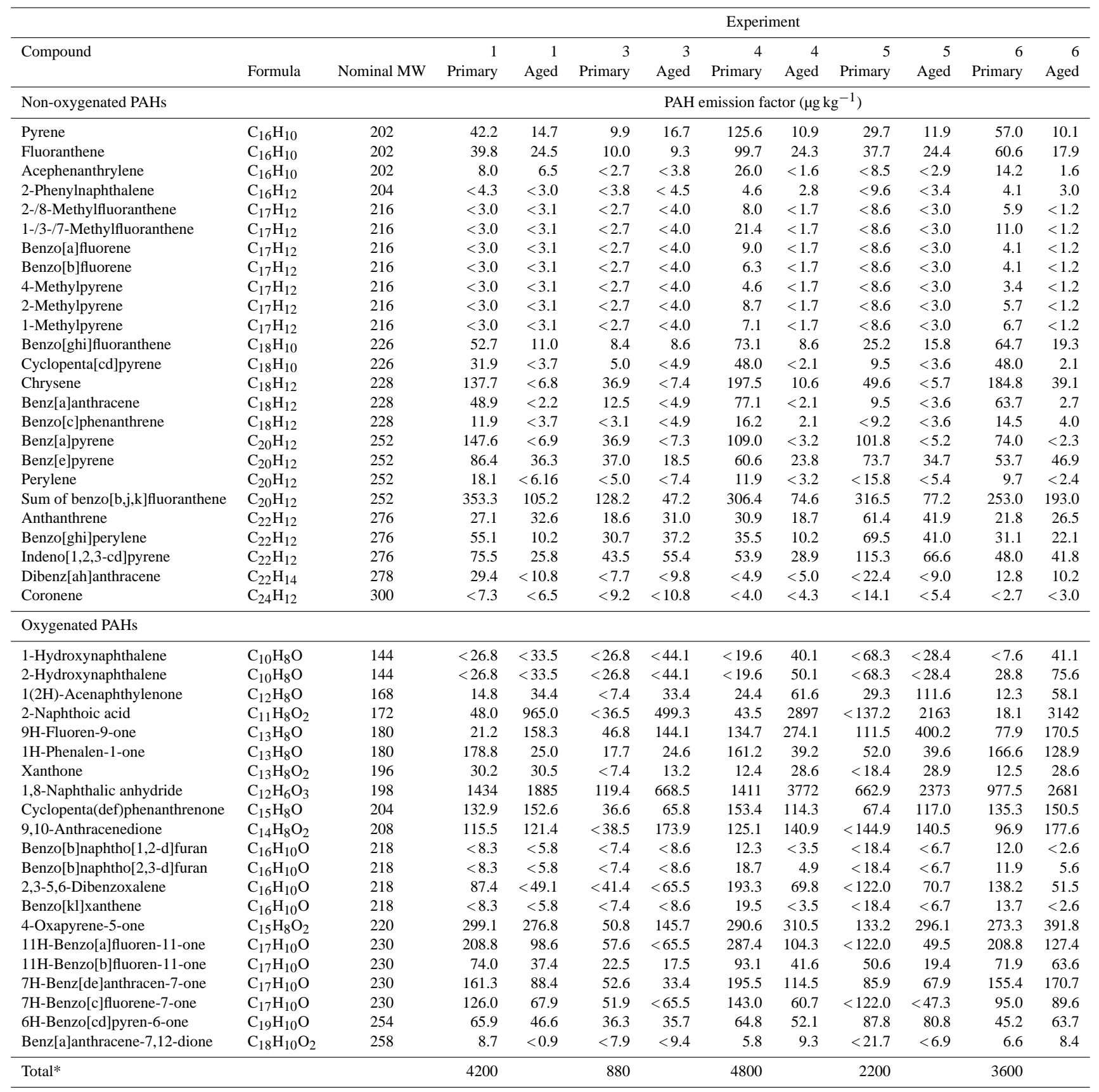

Wall losses and dilution accounted for in reported emission factors. ${ }^{*}$ Sum of PAHs above detection limit.

than ambient measurements (Gianini et al., 2012) and some direct emission studies (e.g., McDonald et al., 2000; Fine et al., 2001, 2002a, 2004a, b; Schauer et al., 2001; Schmidl et al., 2008). Similar values to those found in this study were reported in measurements from previous chamber experiments (Grieshop et al., 2009b; Heringa et al., 2011) and other direct emission studies for flaming conditions with modern small-scale wood burning appliances (Lamberg et al., 2011; Eriksson et al., 2014). Variability in literature OM : BC val- ues arises not only from burn variability but also from measurement/analysis methods. The burner used here is relatively new and expected to burn more efficiently (i.e., lower $\mathrm{OM}: \mathrm{BC}$ ) than burners with older technologies. Also, potential difficulties in separating primary and secondary signal in ambient source apportionment studies can result in incorrectly apportioned primary and secondary signals (Lanz et al., 2010). As OM: BC is typically higher for aged aerosol compared to primary, this results in overestimated $\mathrm{OM}: \mathrm{BC}$ 
ratios. In addition, previous direct emission studies often used lower dilution ratios than used in this study and collected material on quartz fiber filters without the use of an upstream denuder (e.g., McDonald et al., 2000; Fine et al., 2001, 2002a, 2004a, b; Schauer et al., 2001), both of which can result in substantial positive artifacts, as discussed previously (Subramanian et al., 2004). This would result in overestimated $\mathrm{OM}: \mathrm{BC}$ ratios.

AMS and offline filter measurements provide data on the effect of fuel loading on particulate composition. Figure 1 shows the average AMS mass spectrum of the primary emissions from each experiment. The mass spectral signal is separated into different chemical classes (i.e., organic, PAH, nitrate, sulfate, ammonium and chloride) as described in the data analysis section. There were significantly higher PAH contributions to the total organic signal for the high-load experiments compared to the average-load experiments (Fig. 1, Table 1). For the high-load experiments, PAHs contributed $14-17 \%$ to the total organic signal, compared to only 3.4$4.7 \%$ for the average-load experiments (Table 1).

Higher PAH fractions of the total organic mass with higher wood loading are in agreement with Elsasser et al. (2013), who observed an increased signal at higher $\mathrm{m} / \mathrm{z}$ values in AMS mass spectra under high-load conditions, compared to average-load conditions, and attributed this to PAHs. Eriksson et al. (2014) measured PAH contributions to the total OA of 6-14\% under hot, air-starved conditions (generated using higher wood loadings) compared to only $2-4 \%$ under nominal burn conditions during the flaming stage using AMS. Also, previous GC-MS analysis of primary filter samples shows a contribution of PAHs to total PM mass of about $13 \%$ during high-load burning, compared to less than $1 \%$ during average-load burning of beech wood (Orasche et al., 2013).

As filter-based methods can be subject to considerable artifacts and the analysis method used here for PAH quantification from HR-AMS data is novel, results from filter and AMS PAH analysis were compared. The total primary PAH emission factors measured from the filters were $0.88 \mathrm{mg} \mathrm{kg}^{-1}$ (experiment 3) and $4.2 \mathrm{mg} \mathrm{kg}^{-1}$ (experiment 1) for average-load experiments and ranged from 2.2 to $4.8 \mathrm{mg} \mathrm{kg}^{-1}$ for highload experiments (Table 3 ). The primary PAH emission factors measured by AMS ranged from 2.8 to $27 \mathrm{mg} \mathrm{kg}^{-1}$ for average-load experiments and 5.4 to $13 \mathrm{mg} \mathrm{kg}^{-1}$ for highload experiments. AMS PAH emission factors were higher than those determined from the filter analysis, but within a factor of 2-3 for all experiments, except experiment 1, which differed by a factor of 6 . Due to uncertainties associated with both analysis methods, agreement within a factor of $2-3$ is satisfactory.

As a further comparison between the filter and AMS PAH analysis for primary aerosol, compounds with molecular weights corresponding to base ions measured by the AMS above the background level (i.e., 202, 226, 230, 252 and 276 including all associated ions) were compared (Fig. S4 in the Supplement). With the uncertainties associated with both methods, good agreement was observed for molecular weights of 230, 252 and 276, with AMS : filter ratios ranging from $\sim 0.9$ to 2 for the primary emissions. However, for MW 202 and 226, the filter measurements were a factor of 6-15 lower than the AMS measurements. The discrepancies between the filter and AMS measurements were highest for the highest volatility compounds compared, suggesting negative artifacts during the filter sampling, attributed to the use of the denuder.

Discrepancies between the filter and AMS measurements increased with aging (Fig. S4 in the Supplement), particularly for the higher volatility compounds (i.e., MW 202 and 226). The AMS : filter ratios for MW 230, 252 and 276 were 0.9-4, whereas AMS : filter ratios increased drastically for MW 202 and 262 to 13-43. The increased AMS : filter ratios during aging could be due to the formation of oxygenated PAHs, which are more likely to fragment in the AMS than unfunctionalized compounds, and could contribute to the base ion and/or associated ions. Thus, it is not clear whether the AMS signals during aging correspond solely to the compounds identified in the filter samples. During aging, gasphase compounds are oxidized and partition to the particles and the AMS : filter ratios for the lower volatility compounds, which are already predominately in the particle phase, would not change as much during aging as higher volatility compounds, as observed.

The primary organic emission factors for the average-load experiments were a factor of $0.8-18$ times higher than for the high-loading experiments. Although there were higher PAH fractions of the organic mass in the high load cases, there were generally higher primary organic emission factors for the average-load burns compared to the higher load burns, resulting in comparable PAH emission factors. The PAH emission factors in this study are considerably lower than the $196 \mathrm{mg} \mathrm{kg}^{-1}$ found by Orasche et al. (2013) under stable burning conditions of beech wood in an overloaded burner; however, total PM mass determined by Orasche et al. (2013) by weighing dried filter samples was also considerably higher. The higher emission factors observed by Orasche et al. (2013) may be due to differences in burner technologies or sampling methods. The emission dilution ratio affects the partitioning of semi-volatile species, with higher dilution ratios shifting the distribution to the gas phase and thus decreasing particle emission factors (Lipsky and Robinson, 2005). The dilution ratios were only a factor of 4 in Orasche et al. (2013), compared to $\sim 70-300$ in this study. Also, their lack of a denuder upstream of the filter may have resulted in positive artifacts (Subramanian et al., 2004; Orasche et al., 2013).

Due to the semi-volatile nature of many of the PAHs, quantification is also subject to temperature (Boman et al., 2005; Hytonen et al., 2009). While $74 \%$ of pyrene is in the particle phase at $294 \mathrm{~K}, 99.8 \%$ of pyrene is expected to be in the particulate phase at $263 \mathrm{~K}$ (vapor pressure of 
$7.6 \times 10^{-7} \mathrm{~Pa}$ at $263 \mathrm{~K}$, activity coefficient in the organic mass of 1 and a total organic aerosol mass concentration of $30 \mu \mathrm{g} \mathrm{m}^{-3}$ ) (Pankow, 1994; Donahue et al., 2006). These experiments were conducted at $294 \mathrm{~K}$; however, most residential wood combustion occurs when outdoor temperatures are well below this. Thus, if these experiments had been conducted at lower temperatures, particulate PAH emission factors would be higher.

The ion $\mathrm{C}_{2} \mathrm{H}_{4} \mathrm{O}_{2}^{+}$is used as a biomass burning tracer in ambient AMS data. Interestingly, the fraction of $\mathrm{C}_{2} \mathrm{H}_{4} \mathrm{O}_{2}^{+}$ relative to the total primary $\mathrm{OA}\left(f \mathrm{C}_{2} \mathrm{H}_{4} \mathrm{O}_{2}^{+}\right)$was higher in the average-load experiments, ranging from 0.050 to 0.094 , compared to the high load experiments, ranging from 0.012 to 0.029. As summarized by Fitzpatrick et al. (2007), lower burn temperatures favor the formation of products from the pyrolysis of lignin and carbohydrates, including levoglucosan. As the burn temperature increases, the relative contribution of these compounds decreases and products such as polycyclic oxygenates and PAHs dominate. The higher $f \mathrm{C}_{2} \mathrm{H}_{4} \mathrm{O}_{2}^{+}$and lower $f$ PAHs in the average-load experiments suggests that the variability in $f \mathrm{C}_{2} \mathrm{H}_{4} \mathrm{O}_{2}^{+}$was due to lower burn temperatures in the average-load experiments, likely due to different fuel / air ratios.

The chemical differences in organic emissions from highand average-load cases lead to differences in the evolution of these emissions with aging, which has not previously been investigated. Figure 2 shows the evolution of the components measured by AMS, corrected for wall losses and dilution, with photochemical aging. In all experiments, a significant increase in organic mass was observed with photochemistry. At the peak during aging, or at the end of the experiment for experiment 6 , OA increased by a factor of 2.3-3.4 for high loads, whereas by only a factor of 1.4-1.8 for average loads. There was also an increase in PAH concentration with initial aging followed by a decrease with extended aging and eventual stabilization. As shown in Fig. S5 in the Supplement, PAHs above $m / z 200$ were stable or decreased with the initiation of photochemistry, whereas PAH signals at lower molecular weights increased. As discussed previously, the PAH signals in the lower $m / z$ range are likely from PAHs that have undergone fragmentation in the AMS vaporization-ionization process. Functionalized PAHs are more likely to undergo fragmentation than nonfunctionalized PAHs (McLafferty and Turecek, 1993). Increases in these lower $m / z$ PAH signals with aging are likely due to the formation of functionalized PAHs with sufficiently low volatility to partition to the particles.

Chemical composition provides additional insight into the evolution of organic aerosol with aging. Although SOA formation was observed in all experiments, the chemical composition of the aged aerosol was different between the highload and average-load experiments (Fig. 3). Figure 3 shows HR-AMS mass spectra of organic ions categorized by composition. As discussed previously, mass above $\mathrm{m} / z 200$ is not fully included; however, the unaccounted mass is less than $4 \%$ of the total organic mass. Mass spectra of the entire measured $\mathrm{m} / \mathrm{z}$ range and all compound classes are shown in Fig. S6 in the Supplement. Experiments 1, 2, 4 and 5 were compared after an $\mathrm{OH}$ exposure of $1.6 \times 10^{7} \mathrm{molec} \mathrm{cm}^{-3} \mathrm{~h}$. The $\mathrm{OH}$ exposures were not measured during experiments 3 and 6 , and the mass spectra in Fig. 3 correspond to $3 \mathrm{~h}$ aging, which is the average time after lights-on of experiments 1, 2, 4 and 5 corresponding to an $\mathrm{OH}$ exposure of $1.6 \times 10^{7} \mathrm{molec}^{-3} \mathrm{~h}$.

In all mass spectra, the largest peak is $m / z 44$, largely from $\left[\mathrm{CO}_{2}\right]^{+}$, formed from the decarboxylation of organic acids. For the high-load experiments, there are notable aromatic signature ions separated by 12,14 or $16 \mathrm{Da}$, starting at $\left[\mathrm{C}_{6} \mathrm{H}_{5}\right]^{+}\left(m / z\right.$ 77) (e.g., $\left[\mathrm{C}_{7} \mathrm{H}_{7}\right]^{+}(91),\left[\mathrm{C}_{7} \mathrm{H}_{5} \mathrm{O}\right]^{+}(105)$, $\left[\mathrm{C}_{7} \mathrm{H}_{5} \mathrm{O}_{2}\right]^{+}(121),\left[\mathrm{C}_{8} \mathrm{H}_{5} \mathrm{O}_{2}\right]^{+}$(133)) (Fig. 3). Although unfunctionalized PAHs undergo minimal fragmentation in the AMS, functionalized aromatic compounds, including PAHs, are known to fragment when ionized by electron impact to produce other characteristic peaks in the lower $m / z$ region as well (i.e., $<m / z$ 77). Common fragment ions from PAHs containing electronegative substituents are at $\mathrm{m} / \mathrm{z}$ 38, 39, 50, 51, 63-65 and 74-76 (McLafferty and Turecek, 1993). These peaks become more dominant with aging in the highload mass spectra, suggesting an increase in functionalized PAHs with aging (Fig. S7 in the Supplement) (McLafferty and Turecek, 1993). There are also considerable quantities of oxygenated ions at higher $m / z$ values in the high-load experiments (Fig. 3). For example, the fraction of total oxygenated peaks, not including $\left[\mathrm{CO}_{2}\right]^{+}$, at or above $\mathrm{m} / z 80$ is 0.45 for high-load experiment 4 , compared to only $0.15-0.20$ for average-load experiment 2 . This fraction is also higher than the $<0.15$ observed during an $\alpha$-pinene photooxidation experiment (unpublished data) (Fig. S8 in the Supplement).

From the filter analysis, the largest increases with aging were observed for functionalized naphthalene compounds (i.e., 2-naphthoic acid, 1(2H)-acenaphthylenone, 1,8naphthalic anhydride and 2-hydroxynaphthalene), particularly 2-naphthoic acid, which increased by a factor of $\sim 120$ (Fig. 4b, Table 3). In addition to the large increases with aging, 2-naphthoic acid and 1,8-naphthalic anhydride contributed the most to the total PAH signal. This further suggests that the differences in the aged AMS mass spectra between the high and average loads are largely due to the presence of PAHs which have undergone oxidation in the gas phase to form compounds with sufficiently low volatility to partition to the particle phase. The half-life of naphthalene with respect to $\mathrm{OH}$ (average $[\mathrm{OH}]$ from experiments 4 and $5=6.3 \times 10^{6}$ molec $\mathrm{cm}^{-3}$ ) in the chamber was $71 \mathrm{~min}$, and half-lives of methylated naphthalene are even shorter (Atkinson and Aschmann, 1986), which are within the time frame observed for the increase in particulate PAH signal with aging. PTR-MS data show a decrease in $m / z$ 129, likely dominated by naphthalene, during aging, with $\sim 50 \%$ lost within the first $65-70 \mathrm{~min}$ of aging and $\sim 75 \%$ lost by the end of the 


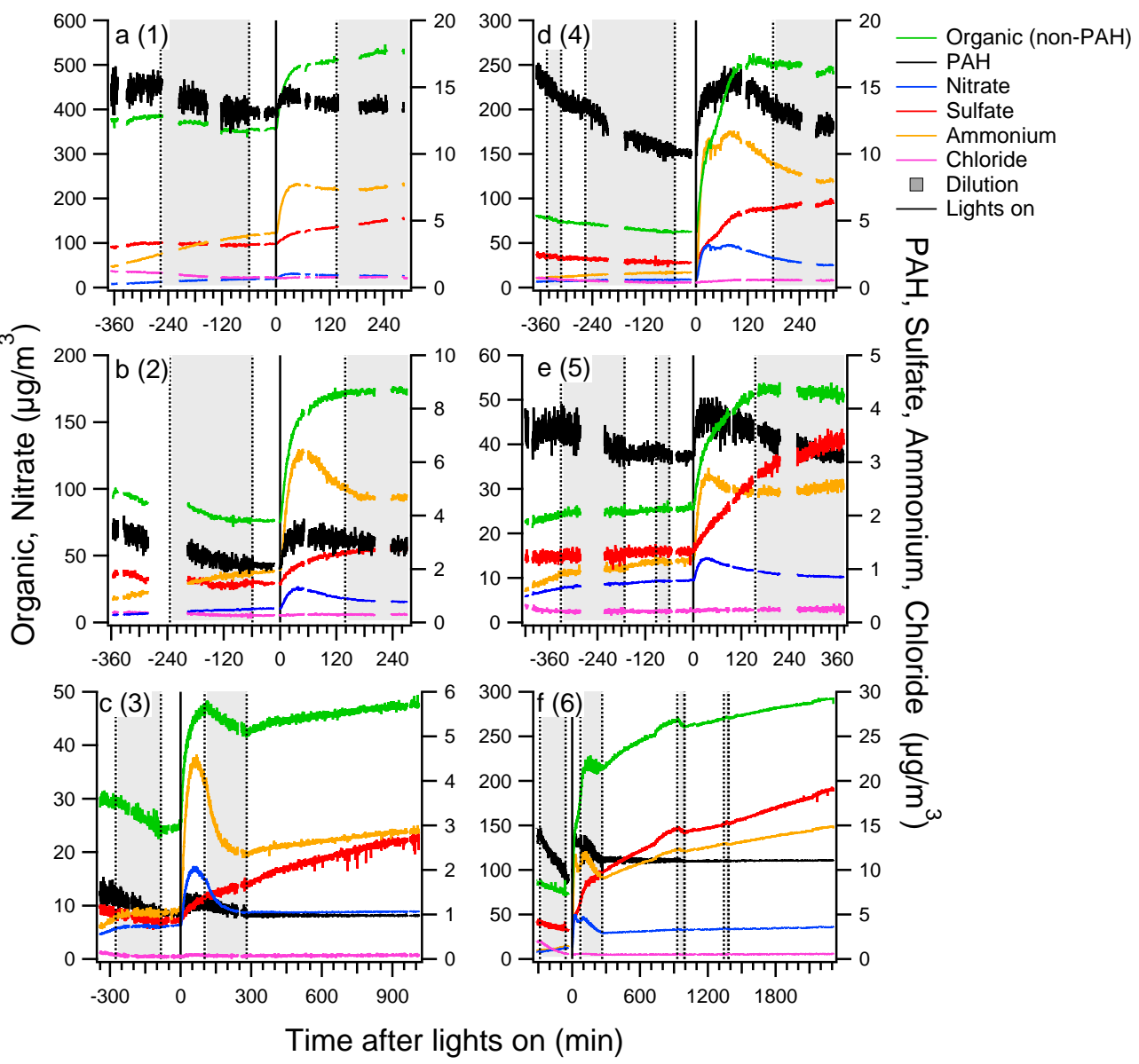

Figure 2. Evolution of components measured by AMS after injection into the chamber until the end of the experiment for (a-c) average-load experiments 1-3 and for (d-f) high-load experiments 4-6. Traces have been corrected for wall losses and dilution. The shaded areas indicate chamber refilling (dilution) periods.

experiment (Fig. S9 in the Supplement). General PAH oxidation pathways are discussed in detail elsewhere (FinlaysonPitts and Pitts, 2000), as well as the formation pathways and identification of naphthalene oxidation products (Kautzman et al., 2010).

The Van Krevelen diagram provides information on the bulk organic aerosol composition and compositional changes with aging (Heald et al., 2010). Figure 5a shows that the primary emissions from the average- and high-load experiments occupy different regions of the plot, further illustrating the bulk compositional differences between the different loading conditions. The primary emissions from the highload experiments had a lower $\mathrm{H}: \mathrm{C}(1.1 \pm 0.1)$ compared to the average-load experiments $(1.47 \pm 0.09)$, due to the larger presence of PAHs (Fig. 5a). For example, $\left[\mathrm{C}_{16} \mathrm{H}_{10}\right]^{+}$, the highest intensity primary PAH ion identified by the AMS, has an $\mathrm{H}: \mathrm{C}$ of only 0.625 . Primary $\mathrm{O}: \mathrm{C}$ was similar for the high-load experiments $(0.3 \pm 0.1)$ compared to the average load $(0.4 \pm 0.1)$. With aging, all experiments showed an ini- tial sharper decrease in $\mathrm{H}: \mathrm{C}$, followed by a more gradual decrease. Throughout aging, $\mathrm{O}: \mathrm{C}$ steadily increased.

The evolution of the fraction of $\left[\mathrm{CO}_{2}\right]^{+}\left(f \mathrm{CO}_{2}^{+}\right)$relative to the fraction of $\left[\mathrm{C}_{2} \mathrm{H}_{3} \mathrm{O}\right]^{+}\left(f \mathrm{C}_{2} \mathrm{H}_{3} \mathrm{O}^{+}\right)$to the total organic signal also provides insight into changes in the chemical composition of the organic material with aging $(\mathrm{Ng}$ et al., 2011). In the AMS, $\left[\mathrm{CO}_{2}\right]^{+}$is formed from the decarboxylation of organic acids during vaporization, whereas $\left[\mathrm{C}_{2} \mathrm{H}_{3} \mathrm{O}\right]^{+}$largely comes from fragmentation of carbonylcontaining compounds, as well as alcohols and peroxides. $\mathrm{Ng}$ et al. (2011) found that the majority of atmospherically relevant SOA measurements fall within a certain space on the $f_{44}$ vs. $f_{43}$ plot. Wood combustion emissions typically lie near the left-hand side of this space, as observed here (Fig. 5b) (Heringa et al., 2011; Heringa et al., 2012).

Within the first $20 \mathrm{~min}$ of aging, in which $\mathrm{H}: \mathrm{C}$ decreased considerably, there was also an increase in $f \mathrm{C}_{2} \mathrm{H}_{3} \mathrm{O}^{+}$for all experiments (Fig. 5b), suggesting an increased fraction of carbonyl, alcohol- and/or peroxide-containing compounds. For the high-load experiments, the majority of compounds 

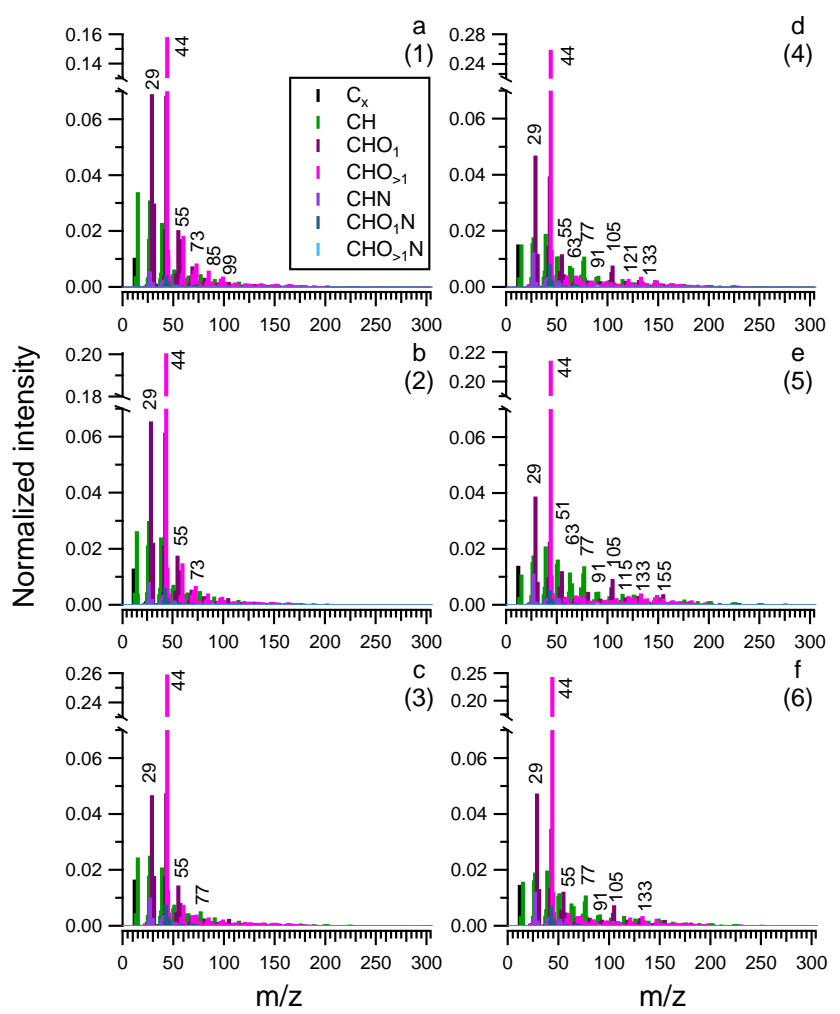

Figure 3. AMS high-resolution mass spectra for average-load experiments (a-c, experiments 1-3) and high-load experiments (df, experiments 4-6). Mass spectra from experiments 1, 2, 4 and 5

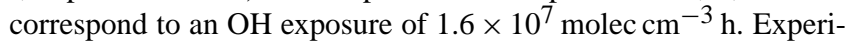
ments 3 and 6 correspond to $3 \mathrm{~h}$ of aging. The legend in (a) applies to $(\mathbf{a}-\mathbf{f})$.

measured from the filters that increase with aging contain at least one carbonyl group. During aging, $f \mathrm{CO}_{2}^{+}$continued to increase, whereas $f \mathrm{C}_{2} \mathrm{H}_{3} \mathrm{O}^{+}$tended to decrease, supporting the more dominant formation of acids with increased aging.

The increase in functionalized naphthalene species measured on the filters with aging suggests notable concentrations of naphthalene were in the gas phase prior to aging during the high-load experiments. Also, phenols, syringol and guaiacol are considerable fractions of wood burning emissions. For oxidation of naphthalene, phenols, syringol and guaiacol, Chhabra et al. (2011) observed near-vertical movement in $f_{44}$ vs $f_{43}$ space, similar to all experiments here. However, in the Van Krevelen diagram, Chhabra et al. (2011) observed movement with a slope close to -1 during oxidation of phenols, syringol and guaiacol, whereas a smaller slope was observed during naphthalene oxidation. The slope after initial oxidation of the high-load experiments was $-0.19 \pm 0.05$, smaller than for the average-load experiments at $-0.4 \pm 0.2$. The smaller slope in the high-load experiments may be due to the higher fraction of PAHs, particularly oxidized naphthalene species, compared to the averageload experiments. Although there are clear differences be-
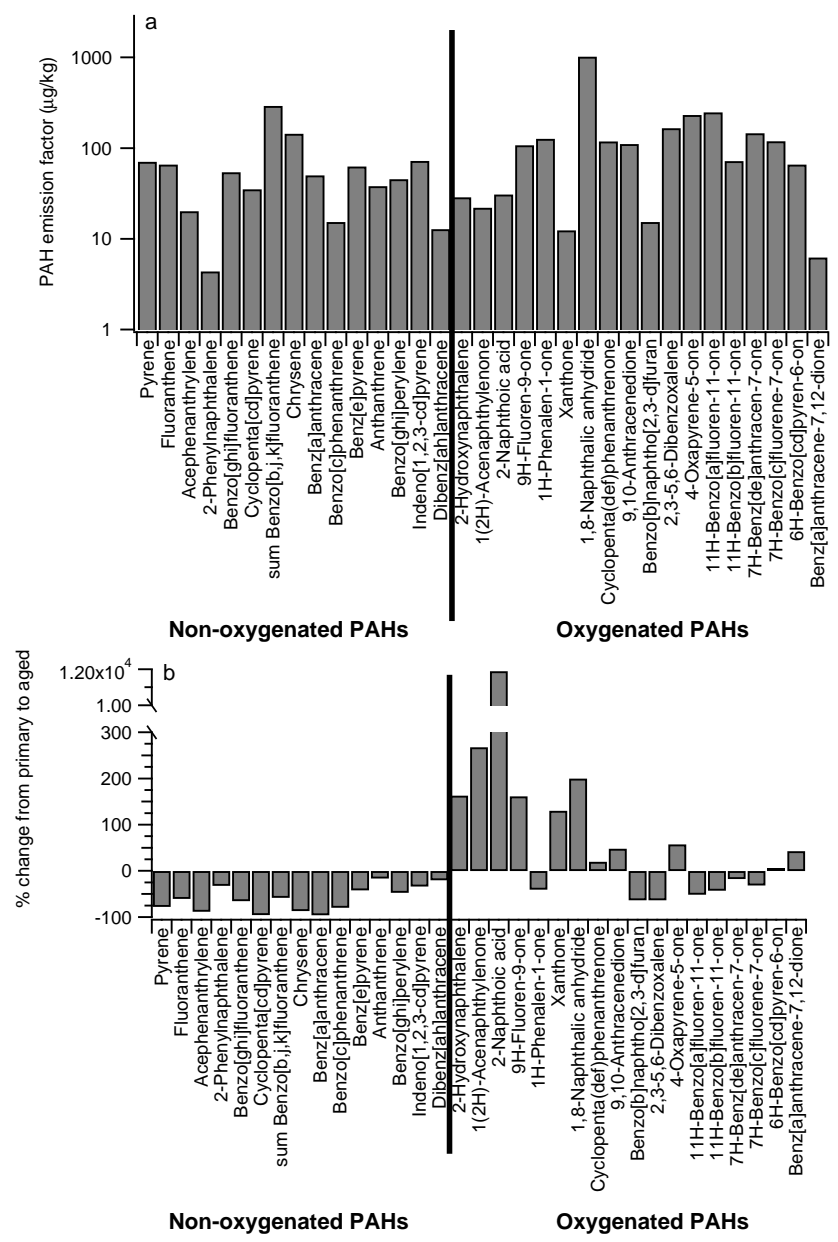

Figure 4. Average (a) PAH emission factor and (b) percent change between primary and aged filter samples for each compound quantitatively measured during filter analysis for high-load experiments.

tween the high- and average-load experiments in the Van Krevelen diagram, it is likely difficult to use these differences to determine wood burning or PAH contribution in ambient measurements, even when dominated by wood burning, due to variability during burns and varying burner parameters and technologies.

\section{Conclusions}

High wood loads result in an increased fraction of PAHs to the total organic aerosol compared to average wood loads. With aging, AMS and filter data indicate that gas-phase compounds, including PAHs, undergo oxidation to form lower volatility products which partition to the particulate phase. As functionalized PAHs often have more deleterious effects on health than their parent analogues (Yu, 2002; Fu et al., 2012), these findings have an impact on toxicological implications. Even when gas-phase PAH emissions are relatively low, their contribution to SOA can be considerable. For ex- 


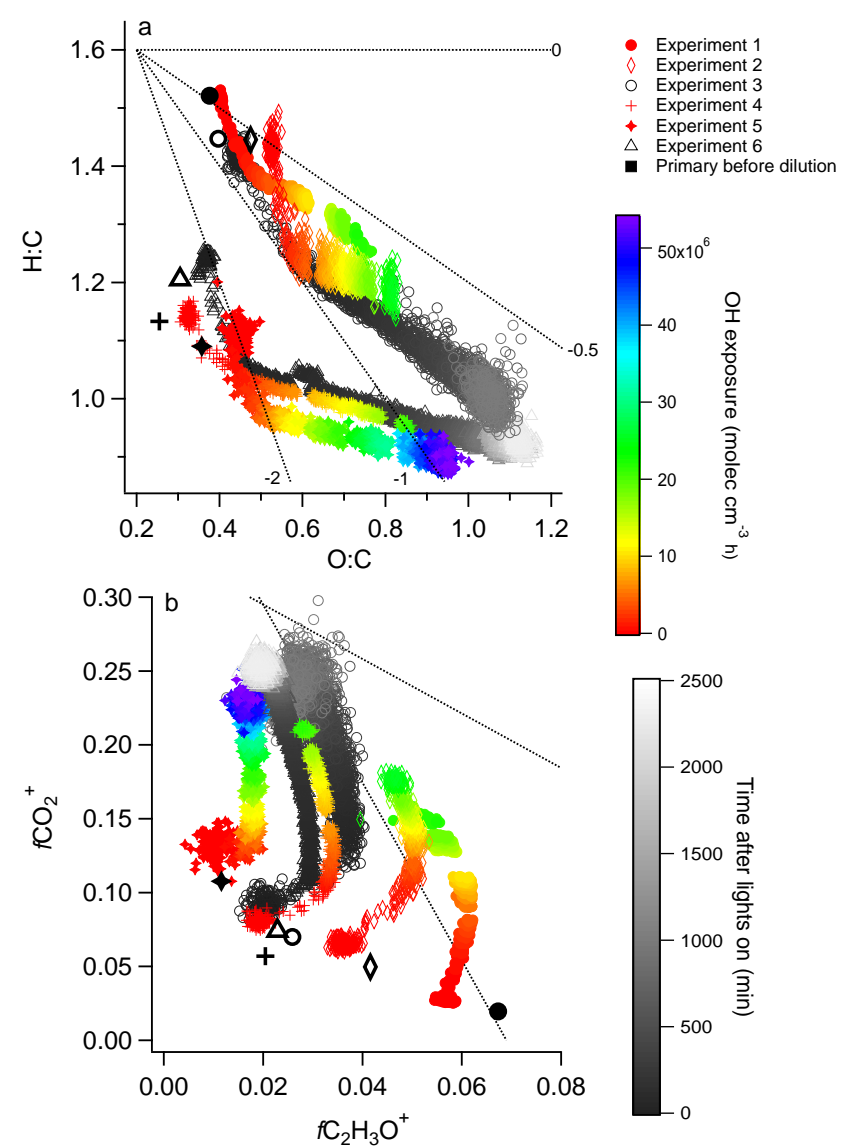

Figure 5. (a) Van Krevelen diagram and (b) $f \mathrm{CO}_{2}^{+}$as a function of $f \mathrm{C}_{2} \mathrm{H}_{3} \mathrm{O}^{+}$determined from HR-AMS analysis. Experiments 1 , 2, 4 and 5 are colored by $\mathrm{OH}$ exposure. Experiments 3 and 6 are colored in greyscale by minutes after lights-on. Thick black markers indicate the primary point for each experiment, immediately after injection and prior to dilution. For comparison, the region in which OA measurements are typically located ( $\mathrm{Ng}$ et al., 2011) is drawn on (b).

ample, using yields from the oxidation of PAHs in the laboratory, Chan et al. (2009) estimated that gas-phase PAHs, despite being only half the concentration of light aromatics, produce 4 times more SOA during the first $12 \mathrm{~h}$ of oxidation of emissions from the burning of pine wood under normal conditions. The toxicological effects on human health of the primary emissions from average and higher load burning and the changes in chemical composition with aging will be detailed in a future publication.

The Supplement related to this article is available online at doi:10.5194/acp-15-2825-2015-supplement.
Acknowledgements. The research leading to these results has received funding from the European Community's Seventh Framework Programme (FP7/2007-2013) under grant agreement no. 290605 (PSI-FELLOW), from the Competence Center Environment and Sustainability (CCES) (project OPTIWARES), from the Swiss National Science Foundation (WOOSHI, grant no. 140590), from EUROSTARS grant E!4825 FC Aeth, and from JR-KROP grant 3211-11-000519. Support from the German Science Foundation (DFG, WooShi-project, grant ZI 764/5-1) and the Virtual Helmholtz Institute HICE - Aerosol and Health (Helmholtz Association, Berlin, Germany) is acknowledged.

Edited by: A. Kiendler-Scharr

\section{References}

Aiken, A. C., Decarlo, P. F., Kroll, J. H., Worsnop, D. R., Huffman, J. A., Docherty, K. S., Ulbrich, I. M., Mohr, C., Kimmel, J. R., Sueper, D., Sun, Y., Zhang, Q., Trimborn, A., Northway, M., Ziemann, P. J., Canagaratna, M. R., Onasch, T. B., Alfarra, M. R., Prévôt, A. S. H., Dommen, J., Duplissy, J., Metzger, A., Baltensperger, U., and Jimenez, J. L.: O/C and OM/OC ratios of primary, secondary, and ambient organic aerosols with high-resolution time-of-flight aerosol mass spectrometry, Environ. Sci. Technol., 42, 4478-4485, 2008.

Allan, J. D., Delia, A. E., Coe, H., Bower, K. N., Alfarra, M. R., Jimenez, J. L., Middlebrook, A. M., Drewnick, F., Onasch, T. B., Canagaratna, M. R., Jayne, J. T., and Worsnop, D. R.: A generalised method for the extraction of chemically resolved mass spectra from Aerodyne aerosol mass spectrometer data, J. Aerosol Sci. 35, 909-922, 2004.

Andreae, M. O. and Merlet, P.: Emission of trace gases and aerosols from biomass burning, Global Biogeochem. Cy., 15, 955-966, 2001.

Atkinson, R. and Aschmann, S. M.: Kinetics of the reactions of naphthalene, 2-methylnaphthalene, and 2,3-dimethylnaphthalene with $\mathrm{OH}$ radicals and with $\mathrm{O}_{3}$ at $295 \pm 1 \mathrm{~K}$, Int. J. Chem. Kinet., 18, 569-573, 1986.

Bari, M. A., Baumbach, G., Brodbeck, J., Struschka, M., Kuch, B., Dreher, W., and Scheffknecht, G.: Characterisation of particulates and carcinogenic polycyclic aromatic hydrocarbons in wintertime wood-fired heating in residential areas, Atmos. Environ., 45, 7627-7634, 2011.

Barmet, P., Dommen, J., DeCarlo, P. F., Tritscher, T., Praplan, A. P., Platt, S. M., Prévôt, A. S. H., Donahue, N. M., and Baltensperger, U.: $\mathrm{OH}$ clock determination by proton transfer reaction mass spectrometry at an environmental chamber, Atmos. Meas. Tech., 5, 647-656, doi:10.5194/amt-5-647-2012, 2012.

Bente, M., Sklorz, M., Streibel, T., and Zimmermann, R.: Thermal desorption-multiphoton ionization time-of-flight mass spectrometry of individual aerosol particles: a simplified approach for online single-particle analysis of polycyclic aromatic hydrocarbons and their derivatives, Anal. Chem., 81, 2525-2536, 2009.

Bølling, A. K., Pagels, J., Yttri, K. E., Barregard, L., Sallsten, G., Schwarze, P. E., and Boman, C.: Health effects of residential wood smoke particles: the importance of combustion conditions and physicochemical particle properties, Part. Fibre Toxicol., 6, doi:10.1186/1743-8977-6-29, 2009. 
Boman, C., Nordin, A., Westerholm, R., and Pettersson, E.: Evaluation of a constant volume sampling setup for residential biomass fired appliances - influence of dilution conditions on particulate and PAH emissions, Biomass Bioenerg., 29, 258-268, 2005.

Burtscher, H., Baltensperger, U., Bukowiecki, N., Cohn, P., Hüglin, C., Mohr, M., Matter, U., Nyeki, S., Schmatloch, V., Streit, N., and Weingartner, E.: Separation of volatile and non-volatile aerosol fractions by thermodesorption: instrumental development and applications, J. Aerosol Sci. 32, 427-442, 2001.

Chan, A. W. H., Kautzman, K. E., Chhabra, P. S., Surratt, J. D., Chan, M. N., Crounse, J. D., Kürten, A., Wennberg, P. O., Flagan, R. C., and Seinfeld, J. H.: Secondary organic aerosol formation from photooxidation of naphthalene and alkylnaphthalenes: implications for oxidation of intermediate volatility organic compounds (IVOCs), Atmos. Chem. Phys., 9, 3049-3060, doi:10.5194/acp-9-3049-2009, 2009.

Chhabra, P. S., Ng, N. L., Canagaratna, M. R., Corrigan, A. L., Russell, L. M., Worsnop, D. R., Flagan, R. C., and Seinfeld, J. H.: Elemental composition and oxidation of chamber organic aerosol, Atmos. Chem. Phys., 11, 8827-8845, doi:10.5194/acp-11-88272011, 2011.

Crippa, M., DeCarlo, P. F., Slowik, J. G., Mohr, C., Heringa, M. F., Chirico, R., Poulain, L., Freutel, F., Sciare, J., Cozic, J., Di Marco, C. F., Elsasser, M., Nicolas, J. B., Marchand, N., Abidi, E., Wiedensohler, A., Drewnick, F., Schneider, J., Borrmann, S., Nemitz, E., Zimmermann, R., Jaffrezo, J.-L., Prévôt, A. S. H., and Baltensperger, U.: Wintertime aerosol chemical composition and source apportionment of the organic fraction in the metropolitan area of Paris, Atmos. Chem. Phys., 13, 961-981, doi:10.5194/acp-13-961-2013, 2013.

DeCarlo, P. F., Kimmel, J. R., Trimborn, A., Northway, M. J., Jayne, J. T., Aiken, A. C., Gonin, M., Fuhrer, K., Horvath, T., Docherty, K. S., Worsnop, D. R., and Jimenez, J. L.: Field-deployable, high-resolution, time-of-flight aerosol mass spectrometer, Anal. Chem., 78, 8281-8289, 2006.

Donahue, N. M., Robinson, A. L., Stanier, C. O., and Pandis, S. N.: Coupled partitioning, dilution, and chemical aging ofsemivolatile organics, Environ. Sci. Technol., 40, 2635-2643, 2006.

Dzepina, K., Arey, J., Marr, L. C., Worsnop, D. R., Salcedo, D., Zhang, Q., Onasch, T. B., Molina, L. T., Molina, M. J., and Jimenez, J. L.: Detection of particle-phase polycyclic aromatic hydrocarbons in Mexico City using an aerosol mass spectrometer, Int. J. Mass Spectrom., 263, 152-170, 2007.

Elsasser, M., Busch, C., Orasche, J., Schön, C., Hartmann, H., Schnelle-Kreis, J., and Zimmermann, R.: Dynamic changes of the aerosol composition and concentration during different burning phases of wood combustion, Energ. Fuel., 27, 4959-4968, 2013

Eriksson, A. C., Nordin, E. Z., Nystrom, R., Pettersson, E., Swietlicki, E., Bergvall, C., Westerholm, R., Boman, C., and Pagels, J. H.: Particulate PAH emissions from residential biomass combustion: time-resolved analysis with aerosol mass spectrometry, Environ. Sci. Technol., 48, 7143-7150, 2014.

Fine, P. M., Cass, G. R., and Simoneit, B. R. T.: Chemical characterization of fine particle emissions from fireplace combustion of woods grown in the northeastern United States, Environ. Sci. Technol., 35, 2665-2675, 2001.

Fine, P. M., Cass, G. R., and Simoneit, B. R. T.: Chemical characterization of fine particle emissions from the fireplace combus- tion of woods grown in the southern United States, Environ. Sci Technol., 36, 1442-1451, 2002a.

Fine, P. M., Cass, G. R., and Simoneit, B. R. T.: Organic compounds in biomass smoke from residential wood combustion: emissions characterization at a continental scale, J. Geophys. Res.-Atmos., 107, 8349, doi:10.1029/2001JD000661, 2002b.

Fine, P. M., Cass, G. R., and Simoneit, B. R. T.: Chemical characterization of fine particle emissions from the fireplace combustion of wood types grown in the midwestern and western United States, Environ. Eng. Sci., 21, 387-409, 2004a.

Fine, P. M., Cass, G. R., and Simoneit, B. R. T.: Chemical characterization of fine particle emissions from the wood stove combustion of prevalent United States tree species, Environ. Eng. Sci., 21, 705-721, 2004b.

Finlayson-Pitts, B. J. and Pitts, J. N. J.: Chemistry of the Upper and Lower Atmosphere - Theory, Experiments, and Applications, Academic Press, San Diego, 2000.

Fitzpatrick, E. M., Ross, A. B., Bates, J., Andrews, G., Jones, J. M., Phylaktou, H., Pourkashanian, M., and Williams, A.: Emission of oxygenated species from the combustion of pine wood and its relation to soot formation, Process Saf. Environ., 85, 430-440, 2007.

Fu, P. P., Xia, Q., Sun, X., and Yu, H.: Phototoxicity and environmental transformation of polycyclic aromatic hydrocarbons (PAHs) - light-induced reactive oxygen species, lipid peroxidation, and DNA damage, J. Environ. Sci. Heal. C, 30, 1-41, 2012.

Gelencsér, A., May, B., Simpson, D., Sánchez-Ochoa, A., KasperGiebl, A., Puxbaum, H., Caseiro, A., Pio, C., and Legrand, M.: Source apportionment of $\mathrm{PM}_{2.5}$ organic aerosol over Europe: primary/secondary, natural/anthropogenic, and fossil/biogenic origin, J. Geophys. Res.-Atmos., 112, D23S04, doi:10.1029/2006JD008094, 2007.

Gianini, M. F. D., Fischer, A., Gehrig, R., Ulrich, A., Wichser, A., Piot, C., Besombes, J. L., and Hueglin, C.: Comparative source apportionment of PM10 in Switzerland for 2008/2009 and 1998/1999 by Positive Matrix Factorisation, Atmos. Environ., 54, 149-158, 2012.

Gorin, C. A., Collett, J. L., and Herckes, P.: Wood smoke contribution to winter aerosol in Fresno, CA, J. Air Waste Manage., 56, 1584-1590, 2006.

Grieshop, A. P., Donahue, N. M., and Robinson, A. L.: Laboratory investigation of photochemical oxidation of organic aerosol from wood fires 2: analysis of aerosol mass spectrometer data, Atmos. Chem. Phys., 9, 2227-2240, doi:10.5194/acp-9-2227-2009, 2009a.

Grieshop, A. P., Logue, J. M., Donahue, N. M., and Robinson, A. L.: Laboratory investigation of photochemical oxidation of organic aerosol from wood fires 1: measurement and simulation of organic aerosol evolution, Atmos. Chem. Phys., 9, 1263-1277, doi:10.5194/acp-9-1263-2009, 2009 b.

Heald, C. L., Kroll, J. H., Jimenez, J. L., Docherty, K. S., DeCarlo, P. F., Aiken, A. C., Chen, Q., Martin, S. T., Farmer, D. K., and Artaxo, P.: A simplified description of the evolution of organic aerosol composition in the atmosphere, Geophys. Res. Lett., 37, L08803, doi:10.1029/2010GL042737, 2010.

Hedberg, E., Kristensson, A., Ohlsson, M., Johansson, C., Johansson, P. A., Swietlicki, E., Vesely, V., Wideqvist, U., and Westerholm, R.: Chemical and physical characterization of emissions 
from birch wood combustion in a wood stove, Atmos. Environ., 36, 4823-4837, 2002.

Hennigan, C. J., Sullivan, A. P., Collett, J. L., and Robinson, A. L.: Levoglucosan stability in biomass burning particles exposed to hydroxyl radicals, Geophys. Res. Lett., 37, L09806, doi:10.1029/2010GL043088, 2010.

Hennigan, C. J., Miracolo, M. A., Engelhart, G. J., May, A. A., Presto, A. A., Lee, T., Sullivan, A. P., McMeeking, G. R., Coe, H., Wold, C. E., Hao, W.-M., Gilman, J. B., Kuster, W. C., de Gouw, J., Schichtel, B. A., Collett Jr., J. L., Kreidenweis, S. M., and Robinson, A. L.: Chemical and physical transformations of organic aerosol from the photo-oxidation of open biomass burning emissions in an environmental chamber, Atmos. Chem. Phys., 11, 7669-7686, doi:10.5194/acp-11-7669-2011, 2011.

Herich, H., Gianini, M. F .D., Piot, C., Močnik, G., Jaffrezo, J. L., Besombes, J. L., Prévôt, A. S. H., and Hueglin, C.: Overview of the impact of wood burning emissions on carbonaceous aerosols and PM in large parts of the Alpine region, Atmos. Environ., 89, 64-75, 2014.

Heringa, M. F., DeCarlo, P. F., Chirico, R., Tritscher, T., Dommen, J., Weingartner, E., Richter, R., Wehrle, G., Prévôt, A. S. H., and Baltensperger, U.: Investigations of primary and secondary particulate matter of different wood combustion appliances with a high-resolution time-of-flight aerosol mass spectrometer, Atmos. Chem. Phys., 11, 5945-5957, doi:10.5194/acp-11-59452011, 2011.

Heringa, M. F., DeCarlo, P. F., Chirico, R., Lauber, A., Doberer, A., Good, J., Nussbaumer, T., Keller, A., Burtscher, H., Richard, A., Miljevic, B., Prévôt, A. S. H., and Baltensperger, U.: Timeresolved characterization of primary emissions from residential wood combustion appliances, Environ. Sci. Technol., 46, 1141811425, 2012.

Horne, P. A. and Williams, P. T.: Influence of temperature on the products from the flash pyrolysis of biomass, Fuel, 75, 10511059, 1996.

Hytonen, K., Yli-Pirila, P., Tissari, J., Grohn, A., Riipinen, I., Lehtinen, K. E. J., and Jokiniemi, J.: Gas-particle distribution of PAHs in wood combustion emission determined with annular denuders, filter, and polyurethane foam adsorbent, Aerosol Sci. Tech., 43, 442-454, 2009.

Iinuma, Y., Boge, O., Grafe, R., and Herrmann, H.: Methylnitrocatechols: atmospheric tracer compounds for biomass burning secondary organic aerosols, Environ. Sci. Technol., 44, 8453-8459, 2010.

IPCC: Climate Change 2007: Mitigation. Contribution of Working Group III to the Fourth Assessment Report of the Intergovernmental Panel on Climate Change, edited by: Metz, B., Davidson, O. R., Bosch, P. R., Dave, R., Meyer L. A., Cambridge University Press, Cambridge, UK and New York, NY, USA, 2007.

IPCC: Climate Change 2013: The Physical Science Basis. Contribution of Working Group I to the Fifth Assessment Report of the Intergovernmental Panel on Climate Change, edited by: Stocker, T. F., Qin, D., Plattner, G.-K., Tignor, M., Allen, S. K., Boschung, J., Nauels, A., Xia, Y., Bex, V., and Midgley, P. M., Cambridge University Press, Cambridge, UK and New York, NY, USA, 2013.

Johansson, L. S., Leckner, B., Gustavsson, L., Cooper, D., Tullin, C., and Potter, A.: Emission characteristics of modern and old- type residential boilers fired with wood logs and wood pellets, Atmos. Environ., 38, 4183-4195, 2004.

Joosten, R., Schumacher, J., Wirth, C., and Schulte, A.: Evaluating tree carbon predictions for beech (Fagus sylvatica L.) in western Germany, Forest Ecol. Manag., 189, 87-96, 2004.

Jordan, T. B. and Seen, A. J.: Effect of airflow setting on the organic composition of woodheater emissions, Environ. Sci. Technol., 39, 3601-3610, 2005.

Kautzman, K. E., Surratt, J. D., Chan, M. N., Chan, A. W. H., Hersey, S. P., Chhabra, P. S., Dalleska, N. F., Wennberg, P. O., Flagan, R. C., and Seinfeld, J. H.: Chemical composition of gasand aerosol-phase products from the photooxidation of naphthalene, J. Phys. Chem. A, 114, 913-934, 2010.

Kim, K.-H., Jahan, S. A., Kabir, E., and Brown, R. J. C.: A review of airborne polycyclic aromatic hydrocarbons (PAHs) and their human health effects, Environ. Int., 60, 71-80, 2013.

Krecl, P., Hedberg Larsson, E., Ström, J., and Johansson, C.: Contribution of residential wood combustion and other sources to hourly winter aerosol in Northern Sweden determined by positive matrix factorization, Atmos. Chem. Phys., 8, 3639-3653, doi:10.5194/acp-8-3639-2008, 2008.

Kroll, J. H. and Seinfeld, J. H.: Chemistry of secondary organic aerosol: formation and evolution of low-volatility organics in the atmosphere, Atmos. Environ., 42, 3593-3624, 2008.

Lamberg, H., Nuutinen, K., Tissari, J., Ruusunen, J., Yli-Pirilä, P., Sippula, O., Tapanainen, M., Jalava, P., Makkonen, U., Teinilä, K., Saarnio, K., Hillamo, R., Hirvonen, M.-R., and Jokiniemi, J.: Physicochemical characterization of fine particles from smallscale wood combustion, Atmos. Environ., 45, 7635-7643, 2011.

Lanz, V. A., Prévôt, A. S. H., Alfarra, M. R., Weimer, S., Mohr, C., DeCarlo, P. F., Gianini, M. F. D., Hueglin, C., Schneider, J., Favez, O., D’Anna, B., George, C., and Baltensperger, U.: Characterization of aerosol chemical composition with aerosol mass spectrometry in Central Europe: an overview, Atmos. Chem. Phys., 10, 10453-10471, doi:10.5194/acp-10-10453-2010, 2010.

Lee, T., Sullivan, A. P., Mack, L., Jimenez, J.L., Kreidenweis, S. M., Onasch, T. B., Worsnop, D. R., Malm, W., Wold, C. E., Hao, W. M., and Collett, J. L.: Chemical smoke marker emissions during flaming and smoldering phases of laboratory open burning of wildland fuels, Aerosol Sci. Tech., 44, 1-5, 2010.

Lipsky, E. M. and Robinson, A. L.: Effects of dilution on fine particle mass and partitioning of semivolatile organics in diesel exhaust and wood smoke, Environ. Sci. Technol., 40, 155-162, 2005.

Mauderly, J. L. and Chow, J. C.: Health effects of organic aerosols, Inhal. Toxicol., 20, 257-288, 2008.

McDonald, J. D., Zielinska, B., Fujita, E. M., Sagebiel, J. C., Chow, J. C., and Watson, J. G.: Fine particle and gaseous emission rates from residential wood combustion, Environ. Sci. Technol., 34, 2080-2091, 2000.

McLafferty, F. W. and Turecek, F.: Interpretation of Mass Spectra, 4th Edn., University Science Books, Mill Valley, CA, USA, 1993.

Mohr, C., DeCarlo, P. F., Heringa, M. F., Chirico, R., Slowik, J. G., Richter, R., Reche, C., Alastuey, A., Querol, X., Seco, R., Peñuelas, J., Jiménez, J. L., Crippa, M., Zimmermann, R., Baltensperger, U., and Prévôt, A. S. H.: Identification and quantification of organic aerosol from cooking and other sources in 
Barcelona using aerosol mass spectrometer data, Atmos. Chem. Phys., 12, 1649-1665, doi:10.5194/acp-12-1649-2012, 2012.

Mohr, C., Lopez-Hilfiker, F. D., Zotter, P., Prévôt, A. S. H., Xu, L., Ng, N. L., Herndon, S. C., Williams, L. R., Franklin, J. P., Zahniser, M. S., Worsnop, D. R., Knighton, W. B., Aiken, A. C., Gorkowski, K. J., Dubey, M. K., Allan, J. D., and Thornton, J. A.: Contribution of nitrated phenols to wood burning brown carbon light absorption in Detling, United Kingdom during winter time, Environ. Sci. Technol., 47, 6316-6324, 2013.

Naeher, L. P., Brauer, M., Lipsett, M., Zelikoff, J. T., Simpson, C. D., Koenig, J. Q., and Smith, K. R.: Woodsmoke health effects: a review, Inhal. Toxicol., 19, 67-106, 2007.

Ng, N. L., Canagaratna, M. R., Jimenez, J. L., Chhabra, P. S., Seinfeld, J. H., and Worsnop, D. R.: Changes in organic aerosol composition with aging inferred from aerosol mass spectra, Atmos. Chem. Phys., 11, 6465-6474, doi:10.5194/acp-11-64652011, 2011.

Orasche, J., Schnelle-Kreis, J., Abbaszade, G., and Zimmermann, R.: Technical Note: In-situ derivatization thermal desorption GC-TOFMS for direct analysis of particle-bound non-polar and polar organic species, Atmos. Chem. Phys., 11, 8977-8993, doi:10.5194/acp-11-8977-2011, 2011.

Orasche, J., Seidel, T., Hartmann, H., Schnelle-Kreis, J., Chow, J. C., Ruppert, H., and Zimmermann, R.: Comparison of emissions from wood combustion. Part 1: Emission factors and characteristics from different small-scale residential heatingappliances considering particulate matter and polycyclic aromatic hydrocarbon (PAH)-related toxicological potential of particle-bound organic species, Energ. Fuel, 26, 6695-6704, 2012.

Orasche, J., Schnelle-Kreis, J., Schön, C., Hartmann, H., Ruppert, H., Arteaga-Salas, J. M., and Zimmermann, R.: Comparison of emissions from wood combustion. Part 2: Impact of combustion conditions on emission factors and characteristics of particle-bound organic species and polycyclic aromatic hydrocarbon (PAH)-related toxicological potential, Energ. Fuel, 27, 1482-1491, 2013.

Ortega, A. M., Day, D. A., Cubison, M. J., Brune, W. H., Bon, D., de Gouw, J. A., and Jimenez, J. L.: Secondary organic aerosol formation and primary organic aerosol oxidation from biomass-burning smoke in a flow reactor during FLAME-3, Atmos. Chem. Phys., 13, 11551-11571, doi:10.5194/acp-1311551-2013, 2013

Pankow, J. F.: An absorption-model of gas-particle partitioning of organic-compounds in the atmosphere, Atmos. Environ., 28, 185-188, 1994.

Paulsen, D., Dommen, J., Kalberer, M., Prévôt, A. S. H., Richter, R., Sax, M., Steinbacher, M., Weingartner, E., and Baltensperger, U.: Secondary organic aerosol formation by irradiation of 1,3,5trimethylbenzene-NOx- $\mathrm{H}_{2} \mathrm{O}$ in a new reaction chamber for atmospheric chemistry and physics, Environ. Sci. Technol., 39, 2668-2678, 2005.

Petit, J.-E., Favez, O., Sciare, J., Canonaco, F., Croteau, P., Močnik, G., Jayne, J., Worsnop, D., and Leoz-Garziandia, E.: Submicron aerosol source apportionment of wintertime pollution in Paris, France by double positive matrix factorization (PMF2) using an aerosol chemical speciation monitor (ACSM) and a multiwavelength Aethalometer, Atmos. Chem. Phys., 14, 1377313787, doi:10.5194/acp-14-13773-2014, 2014.
Pettersson, E., Boman, C., Westerholm, R., Boström, D., and Nordin, A.: Stove performance and emission characteristics in residential wood log and pellet combustion, part 2: wood stove, Energ. Fuel, 25, 315-323, 2011.

Pfaffenberger, L., Barmet, P., Slowik, J. G., Praplan, A. P., Dommen, J., Prévôt, A. S. H., and Baltensperger, U.: The link between organic aerosol mass loading and degree of oxygenation: an apinene photooxidation study, Atmos. Chem. Phys., 13, 64936506, doi:10.5194/acp-13-6493-2013, 2013.

Platt, S. M., El Haddad, I., Zardini, A. A., Clairotte, M., Astorga, C., Wolf, R., Slowik, J. G., Temime-Roussel, B., Marchand, N., Ježek, I., Drinovec, L., Močnik, G., Möhler, O., Richter, R., Barmet, P., Bianchi, F., Baltensperger, U., and Prévôt, A. S. H.: Secondary organic aerosol formation from gasoline vehicle emissions in a new mobile environmental reaction chamber, Atmos. Chem. Phys., 13, 9141-9158, doi:10.5194/acp-13-91412013, 2013.

Saarikoski, S. K., Sillanpaa, M. K., Saarnio, K. M., Hillamo, R. E., Pennanen, A. S., and Salonen, R. O.: Impact of biomass combustion on urban fine particulate matter in Central and Northern Europe, Water Air Soil Poll., 191, 265-277, 2008.

Schauer, J. J., Kleeman, M. J., Cass, G. R., and Simoneit, B. R. T.: Measurement of emissions from air pollution sources. 3. $\mathrm{C}_{1}-\mathrm{C}_{29}$ organic compounds from fireplace combustion of wood, Environ. Sci. Technol., 35, 1716-1728, 2001.

Schmidl, C., Marr, L. L., Caseiro, A., Kotianova, P., Berner, A., Bauer, H., Kasper-Giebl, A., and Puxbaum, H.: Chemical characterisation of fine particle emissions from wood stove combustion of common woods growing in mid-European alpine regions, Atmos. Environ., 42, 126-141, 2008.

Shiraiwa, M., Kondo, Y., Iwamoto, T., and Kita, K.: Amplification of light absorption of black carbon by organic coating, Aerosol Sci. Tech., 44, 46-54, 2010.

Simpson, D., Yttri, K. E., Klimont, Z., Kupiainen, K., Caseiro, A., Gelencsér, A., Pio, C., Puxbaum, H., and Legrand, M.: Modeling carbonaceous aerosol over Europe: analysis of the CARBOSOL and EMEP EC/OC campaigns, J. Geophys. Res.-Atmos., 112, D23S14, doi:10.1029/2006JD008158, 2007.

Slowik, J. G., Stainken, K., Davidovits, P., Williams, L. R., Jayne, J. T., Kolb, C. E., Worsnop, D. R., Rudich, Y., DeCarlo, P. F., and Jimenez, J. L.: Particle morphology and density characterization by combined mobility and aerodynamic diameter measurements. Part 2: Application to combustion-generated soot aerosols as a function of fuel equivalence ratio, Aerosol Sci. Tech., 38, 12061222, 2004.

Subramanian, R., Khlystov, A. Y., Cabada, J. C., and Robinson, A. L.: Positive and negative artifacts in particulate organic carbon measurements with denuded and undenuded sampler configurations, Aerosol Sci. Tech., 38, 27-48, 2004.

Taira, M. and Kanda, Y.: Continuous generation system for lowconcentration gaseous nitrous-acid, Anal. Chem., 62, 630-633, 1990.

Turpin, B. J., Saxena, P., and Andrews, E.: Measuring and simulating particulate organics in the atmosphere: problems and prospects, Atmos. Environ., 34, 2983-3013, 2000.

Ward, D. E. and Radke, L. F.: Emissions measurements from vegetation fires: A comparative evaluation of methods and results, in: Fire in the Environment: The Ecological, Atmospheric, and 
Climatic Importance of Vegetation Fires, edited by: Crutzen, P. J. and Goldammer, J. G., Jolm Wiley \& Sons Ltd., 1993.

Weimer, S., Alfarra, M. R., Schreiber, D., Mohr, M., Prévôt, A. S. H., and Baltensperger, U.: Organic aerosol mass spectral signatures from wood-burning emissions: influence of burning conditions and wood type, J. Geophys. Res.-Atmos., 113, D10304, doi:10.1029/2007JD009309, 2008.

Weitkamp, E. A., Sage, A. M., Pierce, J. R., Donahue, N. M., and Robinson, A. L.: Organic aerosol formation from photochemical oxidation of diesel exhaust in a smog chamber, Environ. Sci. Technol., 41, 6969-6975, 2007.

Williams, L. R., Gonzalez, L. A., Peck, J., Trimborn, D., McInnis, J., Farrar, M. R., Moore, K. D., Jayne, J. T., Robinson, W. A., Lewis, D. K., Onasch, T. B., Canagaratna, M. R., Trimborn, A., Timko, M. T., Magoon, G., Deng, R., Tang, D., de la Rosa Blanco, E., Prévôt, A. S. H., Smith, K. A., and Worsnop, D. R.: Characterization of an aerodynamic lens for transmitting particles greater than 1 micrometer in diameter into the Aerodyne aerosol mass spectrometer, Atmos. Meas. Tech., 6, 3271-3280, doi:10.5194/amt-6-3271-2013, 2013.
Yee, L. D., Kautzman, K. E., Loza, C. L., Schilling, K. A., Coggon, M. M., Chhabra, P. S., Chan, M. N., Chan, A. W. H., Hersey, S. P., Crounse, J. D., Wennberg, P. O., Flagan, R. C., and Seinfeld, J. H.: Secondary organic aerosol formation from biomass burning intermediates: phenol and methoxyphenols, Atmos. Chem. Phys., 13, 8019-8043, doi:10.5194/acp-13-8019-2013, 2013.

Yu, H. T.: Environmental carcinogenic polycyclic aromatic hydrocarbons: photochemistry and phototoxicity, J. Environ. Sci. Heal. C, 20, 149-183, 2002.

Zhang, J., Fan, X., Graham, L., Chan, T. W., and Brook, J. R.: Evaluation of an annular denuder system for carbonaceous aerosol sampling of diesel engine emissions, J. Air Waste Manage., 63 , 87-99, 2012.

Zhang, X., Cappa, C. D., Jathar, S. H., McVay, R. C., Ensberg, J. J., Kleeman, M. J., and Seinfeld, J. H.: Influence of vapor wall loss in laboratory chambers on yields of secondary organic aerosol, $\mathrm{P}$. Natl. Acad. Sci. USA, 111, 5802-5807, 2014. 